\title{
Cellular Responses to Proteasome Inhibition: Molecular Mechanisms and Beyond
}

\author{
Nicolas Albornoz ${ }^{1}$, Hianara Bustamante ${ }^{2}$, Andrea Soza ${ }^{1}$ and Patricia Burgos ${ }^{1, *}$ \\ 1 Centro de Biología Celular y Biomedicina (CEBICEM), Facultad de Medicina y Ciencia, \\ Universidad San Sebastián, Lota 2465, Santiago 7510157, Chile \\ 2 Instituto de Microbiología Clínica, Facultad de Medicina, Universidad Austral de Chile, \\ Valdivia 5110566, Chile \\ * Correspondence: patricia.burgos@uss.cl; Tel.: +56-2-22606309
}

Received: 31 May 2019; Accepted: 1 July 2019; Published: 10 July 2019

check for updates

\begin{abstract}
Proteasome inhibitors have been actively tested as potential anticancer drugs and in the treatment of inflammatory and autoimmune diseases. Unfortunately, cells adapt to survive in the presence of proteasome inhibitors activating a variety of cell responses that explain why these therapies have not fulfilled their expected results. In addition, all proteasome inhibitors tested and approved by the FDA have caused a variety of side effects in humans. Here, we describe the different types of proteasome complexes found within cells and the variety of regulators proteins that can modulate their activities, including those that are upregulated in the context of inflammatory processes. We also summarize the adaptive cellular responses activated during proteasome inhibition with special emphasis on the activation of the Autophagic-Lysosomal Pathway (ALP), proteaphagy, p62/SQSTM1 enriched-inclusion bodies, and proteasome biogenesis dependent on Nrf1 and Nrf2 transcription factors. Moreover, we discuss the role of IRE1 and PERK sensors in ALP activation during ER stress and the involvement of two deubiquitinases, Rpn11 and USP14, in these processes. Finally, we discuss the aspects that should be currently considered in the development of novel strategies that use proteasome activity as a therapeutic target for the treatment of human diseases.
\end{abstract}

Keywords: proteasome; immunoproteasome; autophagy

\section{Introduction}

In cells, protein biosynthesis is constantly assisted by molecular chaperones in order to avoid accumulation of unfolded proteins and cellular stress [1,2]. The Ubiquitin-Proteasome System (UPS) is one crucial mechanism involved in the degradation of unfolded proteins that have failed quality control. The UPS serves as the major protein quality control system in the eukaryotic cells, responsible for approximately $80 \%-90 \%$ of the cellular protein degradation [3]. It includes most cytosolic and nuclear proteins, short and long-lived proteins, as well as unfolded proteins, all of which are finally degraded by the proteasome [4]. First, cargoes are tagged with ubiquitin $(\mathrm{Ub})$ conjugates through the sequential action of three enzymatic activities E1, E2, and E3 [3,5]. Then, cargoes are recognized by $\mathrm{Ub}$ receptors in the proteasome, and finally, $\mathrm{Ub}$ conjugates are removed by the action of deubiquitinase enzymes (DUBs) [6]. After this coordination of events the substrates are finally translocated and degraded through the proteolytic chamber of the $20 \mathrm{~S}$ proteasome [6]. Interestingly, in autoimmune and inflammatory diseases or cancer, an increase in the activity of the proteasome is found, a feature that has been directly linked with the progression of these diseases. Thus, inhibition of the proteasome is currently considered as an attractive target for therapeutic intervention with a direct impact on the UPS pathway $[7,8]$. 


\section{Proteasome Composition}

\subsection{The 20S Proteasome: The Proteolytic Core}

The proteasome is formed by the proteolytic core named 205 proteasome that contains the catalytic subunits needed for the proteolysis of the substrates [9,10]. The 20S proteasome has a cylinder-like structure constituted of 28 proteins arranged in four heptameric rings. The two external rings are composed of seven different $\alpha$ subunits $(\alpha 1-7)$ and the two internal rings are composed of seven different $\beta$ subunits ( $\beta$ 1-7). The $\alpha$-subunits regulate the entry of the substrate to the $20 S$ proteasome and the interaction with the regulatory particles. The $\beta$ subunits constitute the proteolytic core where $\beta 1, \beta 2$, and $\beta 5$ subunits have caspase-like, trypsin-like, and chymotrypsin-like activities, respectively [11,12]. In mammalian cells, there are three inducible beta subunits named $\beta 1 i, \beta 2 i$ and $\beta 5 \mathrm{i}$, expressed in response to pro-inflammatory cytokines, especially interferon- $\gamma$ during infections, cancer, inflammation, and autoimmune diseases [13-15]. Incorporation of these inducible subunits form a new type of $20 \mathrm{~S}$ proteasome called the immunoproteasome, which is found predominantly, but not exclusively, in cells of the immune system specialized in major histocompatibility complex (MHC) Class I antigen presentation [16] (Figure 1). Additionally, the immunoproteasome promotes differentiation of specific populations of immune cells [17-19].

\subsection{Proteasome Regulators}

\subsubsection{PA700: The $19 S$ Regulatory Particle (RP)}

The 19S RP, also known as PA700, binds to the 20S proteasome in an ATP-dependent manner [20], either to one or both ends, forming the $26 \mathrm{~S}$ or the $30 \mathrm{~S}$ proteasome, respectively [21-24] (Figure 1). The 19S RP is subdivided into two sub-complexes, the base and the lid. The base is composed of 10 integral subunits. Four of these are non-ATPase subunits (Rpn1, Rpn2, Rpn10 and Rpn13) that participate in the recognition of polyubiquitylated substrates through different mechanisms. While Rpn10 and Rpn13 bind polyubiquitylated substrates directly [25,26], Rpn1 and Rpn2 dock $\mathrm{Ub}$ processing factors that serve as shuttles, which interact simultaneously with polyubiquitylated substrates and the proteasome [27]. Several of these shuttles have been characterized including Rad23, Dsk2, and Ddi1 [25,28,29]. The other base subunits are AAA-ATPase subunits (Rpt1-Rpt6) organized in a ring that contributes to the ATP hydrolysis needed for the unfolding, opening and entry of the substrates through the $20 \mathrm{~S}$ proteasome [30-32]. On the other hand, the lid consists of nine different Rpn subunits (Rpn3, Rpn5-9, Rpn11, Rpn12, and Rpn15 (Dss1/Sem1)), which form a horseshoe-shaped structure. One key step that takes place in the lid is the deubiquitylation of the incoming substrates carried out by the structural DUB Rpn11, a highly conserved metalloprotease from yeast to human [33,34], which also helps to maintain a sufficient pool of free Ub molecules within the cells [35]. The other non-structural DUB that is transiently associated to the 19S RP is called Ubiquitin Specific Protease 14 (USP14) [36,37]. Interestingly, USP14 causes a delay in the degradation of proteasome substrates, acting as a negative regulator of the proteasome [38,39]. In agreement with these findings, selective pharmacological inhibition of USP14 enhances the proteolysis of several proteasome substrates [39-41].

\subsubsection{Proteasome Regulators: PA28 $\alpha \beta$, PA28 $\gamma$ and PA200 Complexes}

Two proteasome activator (PA)28 complexes composed by seven subunits have been described, the hetero-oligomer PA28 $\alpha \beta$ present preferentially in the cytosol [42], and the homo-oligomer PA28 $\gamma$ present only in the nucleus [43] (Figure 1). In contrast to the 19S RP, the PA28 complexes bind to the $20 S$ proteasome (constitutively and inducibly) in an ATP-independent manner [23,44,45]. However, similar to the 19S RP, PA28 complexes bind to the 20S proteasomes either to one or both ends forming the 20S-PA28 $\alpha \beta$ or PA28 $\alpha \beta-20 S-P A 28 \alpha \beta$ complexes. Moreover, the 20 s proteasome can bind to the 19S RP and PA28 $\alpha \beta$ simultaneously forming a hybrid proteasome particle $[46,47]$. 
Interferon- $\gamma$ causes the specific up-regulation of PA28 $\alpha \beta$, but not in PA28 $\gamma$ [48-50]. High levels of PA28 $\alpha \beta$ and the immunoproteasome during inflammation explain the elevated diversity of peptides during MHC class I antigen presentation [47,51]. Interestingly, PA28 $\alpha \beta$ and the immunoproteasome have protective functions during oxidative stress conditions [52-54], embryonic stem cell differentiation [55] and obesity [56], indicating the relevance of their function during cellular stress scenarios.

In contrast to PA28 $\alpha \beta$, PA28 $\gamma$ is more related with processes such as cell cycle [57,58], DNA repair [59,60], chromosome stability and RNA splicing [61,62], but not with antigen presentation [63,64].

Finally, similar to the PA28 $\gamma$, there is another nuclear protein called PA200 that binds the 20S proteasome stimulating the hydrolysis of small peptides only, in an ATP-independent manner, process that is involved in DNA repair [65]. Additionally, it has been reported that PA200 participates in genomic stability [66,67], maintenance of glutamine homeostasis in cancer [68], and spermatogenesis [69], but its function is not fully understood.

\subsubsection{ECM29 and PSMF1: Two Interesting Regulators of the Proteasome Function}

ECM29 is a large protein that regulates the function of the proteasome in different forms. It collaborates in the assembly and disassembly of the $26 \mathrm{~S}$ proteasome, as the abundance of ECM29 seems to be critical for these functions [70]. ECM29 tethers the 19S RP to the 20S core, stabilizing the 20S-19S RP interaction promoting its complete assembly [70] (Figure 1). Once this step is completed, ECM29 is released and degraded by the nascent 26S proteasome [71]. In contrast, it has been shown that, under oxidative conditions, ECM29 promotes the disassembly of the 26S proteasome [72], favoring the assembly of the immunoproteasome with its regulator PA28 $\alpha \beta$ that in turns enhances the removal of oxidized proteins [72].

Other functions for ECM29 have been proposed, including its possible role in the quality control of the proteasome. It has been observed that ECM29 has preference for aberrant $20 \mathrm{~S}$ proteasomes such as mutated versions of the proteasome or ATP-depleted proteasome particles [73]. Indeed, there is evidence that ECM29 mediates the localization of the proteasome in specific cellular compartments dependent on microtubules and motor proteins by mechanisms still not fully understood [74].

Another regulator of the proteasome is the $31 \mathrm{kDa}$ protein PSMF1, also known as proteasome inhibitor (PI)31, which acts as an inhibitor of the proteasome by direct binding to the $\alpha$-subunits of the $20 \mathrm{~S}$ proteasome or by binding to the $19 \mathrm{~S}$ regulatory particle [75,76] (Figure 1). Interestingly, the inhibitory role of the PSMF1 in the 20S proteasome can be counteracted by active $\mathrm{p} 97 /$ valosin-containing protein (VCP), an ATPase type II protein that hijacks PSMF1 out of the proteasome [77]. In agreement with this finding, pharmacological inhibition of p97/VCP reduces proteasome activity [77]. This activity reduction could be due to the inability of p97/VCP to hijack PSMF1, or to the role of p97/VCP, in collaboration with shuttle factors, in the delivery and unfolding of polyubiquitylated substrates to the proteasome $[78,79]$.

\subsubsection{Regulation of Proteasome Assembly and Function by E3 Ligases}

Cells contain approximately one thousand E3 ligases that explain the high degree of substrate specificity. E3 ligases are divided into three subclasses based on their structural and biochemical features: Homologous to E6-AP carboxy terminus (HECT), really interesting new gene (RING) fingers, and U-box domains. The RING finger subclass is subdivided into two subfamilies: Cullin-containing RING-finger ligases (CRLs) and those in which the RING-finger and substrate binding domains are contained on the same polypeptide. Regardless of the well-known role of E3 ligases on proteasome substrates, it is also accepted that they have a role in the ubiquitylation of a variety of proteasome subunits [80-83]. For instance, the E3 RING ligase Not4 triggers direct ubiquitylation of the Rpt5 subunit, playing a crucial function in $26 \mathrm{~S}$ proteasome assembly [84]. In agreement with this study, it was previously shown that deletion of Not4 was correlated with instability of the 26S proteasome leading to dissociation of the 20S proteasome and 19S RP, accumulation of polyubiquitylated proteins and a decrease in the levels of free $\mathrm{Ub}$ [85]. Some of these effects were explained by the finding 
that Not4 interacts with ECM29, a protein involved in 26S proteasome stabilization [85]. Authors described that, in the absence of Not4, ECM29 was no longer associated to the proteasome which in part explained the proteasome instability [85]. In addition to Not4, it has been shown that the E3 U-box ligase SNEV (senescence evasion factor) is also mediating the efficiency of proteasome function by the delivery of ubiquitylated substrates to the proteasome via direct binding to $\beta 7$ subunit on the $20 \mathrm{~S}$ proteasome [86]. Finally, the E3 HECT ligase UBE3A, is an enzyme implicated in the ubiquitylation of a variety of proteasome subunits, post-translational modifications that have a positive impact in proteasome activity [87]. In this regard, it has been shown that catalytic defective mutations in UBE3A, are associated with the human Angelman syndrome, resulting in an overall inhibitory effect on the proteolytic activity of the proteasome [88]. Although several findings indicate that ubiquitylation of proteasome subunits plays a positive role on proteasome function, there is still a controversy about this conclusion [80].

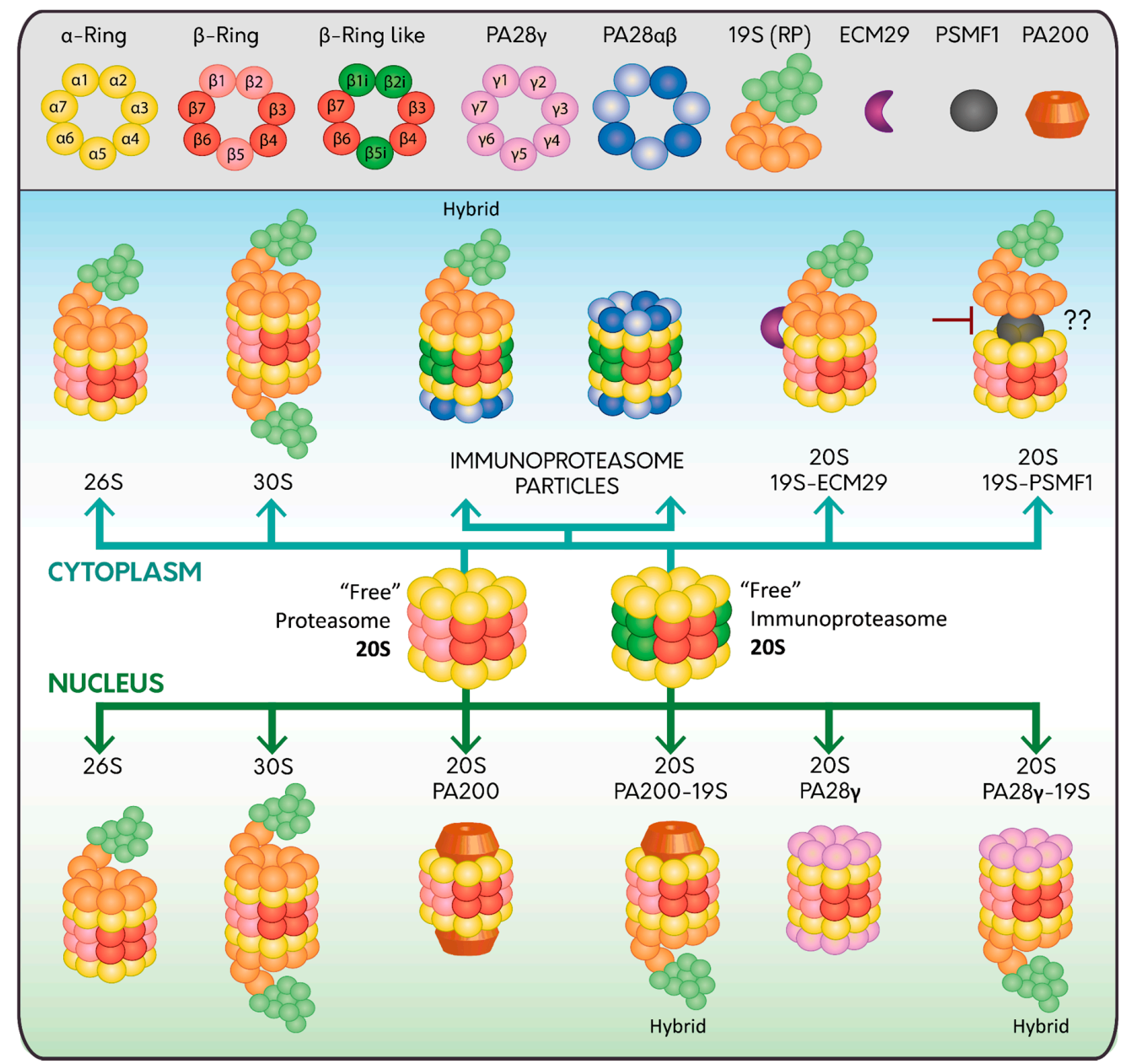

Figure 1. Proteasome assembly and its regulators. The constitutive $20 \mathrm{~S}$ proteasome is assembled in $\alpha$ (Yellow) and $\beta$ (Red) heptameric rings, constituting subunits $\beta 1, \beta 2, \beta 5$ of the catalytic core (Light Red); meanwhile the 20S immunoproteasome catalytic core has three inducible beta subunits named $\beta 1 \mathrm{i}, \beta 2 \mathrm{i}$ and $\beta 5 \mathrm{i}$ (Dark Green). Both types of proteasomes are found without regulators, indicated as "free" or can be associated with 19S RP (Light Orange and Light Green) either at one or both ends forming the $26 \mathrm{~S}$ or $30 \mathrm{~S}$ proteasome, respectively; or with the PA28 complexes either at one or both ends; PA28 $\alpha \beta$

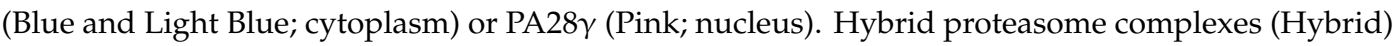
are also found when the catalytic core is simultaneously associated with 19S RP and another type of regulator (PA28 $\alpha \beta$, PA28 $\gamma$ and PA200). Specific regulators in the cytoplasm are ECM29 (Purple) and PSMF1 (Grey), which can modify the assembly or activity of the proteasome; while in the nucleus the main proteasome regulator is PA200 (Dark Orange). 


\section{Pharmacological Inhibitors of the Proteasome Function}

\subsection{S Proteasome Inhibitors}

Several reversible and irreversible proteasome inhibitors have been described to date, which in general target the active sites of the $20 S$ proteolytic core. Among these, we found the peptide aldehydes (ALLN, MG132 and MG115), peptide boronates (PS-341 or bortezomib), epoxyketones (carfilzomib and epoxomicin), and a metabolite isolated from Streptomyces called lactacystin [89] (Figure 2). As many of these inhibitors negatively impact cell survival and proliferation processes they are currently considered excellent triggers of cell death and they are an attractive niche for the treatment of cancer [90-93] and inflammatory diseases [94-98].

One of the most widely used proteasome inhibitors in basic research is MG132. This inhibitor binds to the $\beta 5$ subunit of the $20 S$ proteasome in a reversible manner in the low $\eta \mathrm{M}$ range. However, in high concentrations (low $\mu \mathrm{M}$ range), MG132 can also bind to the $\beta 1$ and $\beta 2$ subunits of the $20 \mathrm{~S}$ proteasome [99]. Moreover, it can also inhibit other proteases including calpains and cathepsins in high concentrations [100]. Regardless of these features, MG132 is still widely used in in vitro studies but with the appropriate controls [99]. MG132 is capable of inducing apoptosis in tumor cells [101], however, and similar to what happens in the presence of other proteasome inhibitors, tumor cells can adapt and live in the presence of this type of inhibitors through the activation of a series of mechanisms that we discuss further.

Currently only three proteasome inhibitors have been approved by the Food and Drug Administration (FDA). The first one was bortezomib approved in 2003 for the treatment of multiple myeloma and mantle cell lymphoma [102]. Bortezomib binds to $\beta 5$ and $\beta 5 \mathrm{i}$ subunits and to a lesser extent to $\beta 2$ and $\beta 1$ subunits causing the inhibition of the $20 \mathrm{~S}$ proteasome, as well as the immunoproteasome, in a slightly reversible manner $[103,104]$. The second one is carfilzomib, a proteasome inhibitor with improved properties compared to bortezomib [105], which was approved by the FDA in 2012 [106]. Carfilzomib binds to the catalytic $\beta 5$ and $\beta 5$ i subunits but with a greater affinity than bortezomib and in an irreversible manner $\left(\mathrm{IC}_{50}\right.$ values of less than $\left.10 \mathrm{nM}\right)[107,108]$. The irreversible mechanism of carfilzomib allows a sustained and durable inhibition of the proteasome, a characteristic that improves its efficacy as a therapeutic agent [109]. The third one is ixazomib, the first oral proteasome inhibitor approved by the FDA in 2015. In low doses ixazomib binds specifically to the $\beta 5$ subunit of the $20 \mathrm{~S}$ proteasome and in a reversible manner. However, in high doses it can also bind to $\beta 1$ and $\beta 2$ subunits causing the massive accumulation of intracellular ubiquitylated proteins [110]. In comparison to bortezomib, it is thought that ixazomib offers an improvement in terms of its pharmacokinetic and pharmacodynamic profiles, however its therapeutic advantages have not been fully investigated yet in randomized clinical trials including bortezomib or carfilzomib [111].

Importantly, all FDA approved proteasome inhibitors present several side-effects in patients, including diarrhea, hematologic toxicities, peripheral neurophaties and fatigue, among other symptoms [112]. This highlights the need of better therapies including the clinical development of combinatory drugs to avoid these side-effects. In addition to this, it is known that the current inhibitors have a limited effect on solid tumors, indicating the importance of new drug discovery.

One promising drug is marizomib, a new proteasome inhibitor derived from a marine Actinomyces, which inhibits all three catalytic subunits of the $20 \mathrm{~S}$ proteasome in an irreversible manner, both in vitro and in vivo [113,114]. Marizomib is currently under clinical trials showing good safety and efficacy profiles in multiple myeloma compared to other similar inhibitors [115]. Therefore, marizomib is considered a promising therapeutic strategy to be used in the treatment of solid tumors.

\subsection{Immunoproteasome Inhibitors}

Immunoproteasome is highly expressed during the course of inflammation and in different types of cancer [116-118]. Therefore, the immunoproteasome is currently the focus of several studies in biomedicine. In recent years, the upregulation of the immunoproteasome has been reported in a number of inflammatory 
and autoimmune diseases, such as ulcerative colitis [119], chronic active hepatitis [120], inflammatory bowel disease (IBD) [121,122], and Crohn's disease [123]. In this regard, it has been shown that pharmacological inhibition of the immunoproteasome prevents lupus- and rheumatoid arthritis-like diseases, experimental colitis and colitis-associated cancer, Hashimoto's thyroiditis, acute myocarditis, microglial activation following central nervous system injury, and allograft rejection in mouse models [19]. These findings strongly indicate that selective inhibition of the immunoproteasome is an attractive pharmacological strategy for the treatment of these diseases.

To date, most studies on immunoproteasome inhibitors have been on PR-957 [124] and PR-924 [125,126], which bind selectively and irreversibly to the $\beta 5 i$ subunit of the immunoproteasome [127] (Figure 2). Moreover, and in contrast to bortezomib and carfilzomib, PR-957 only inhibits the immunoproteasome, without showing any effect on the 20S constitutive proteasome [124,127]. PR-924 is 100-fold more selective for $\beta 5 \mathrm{i}$ than to $\beta 5$ compared to bortezomib and carfilzomib, which can target other activities as well [125].

This high selectivity opens up very promising treatments in the future that should reduce side effects in humans [128].

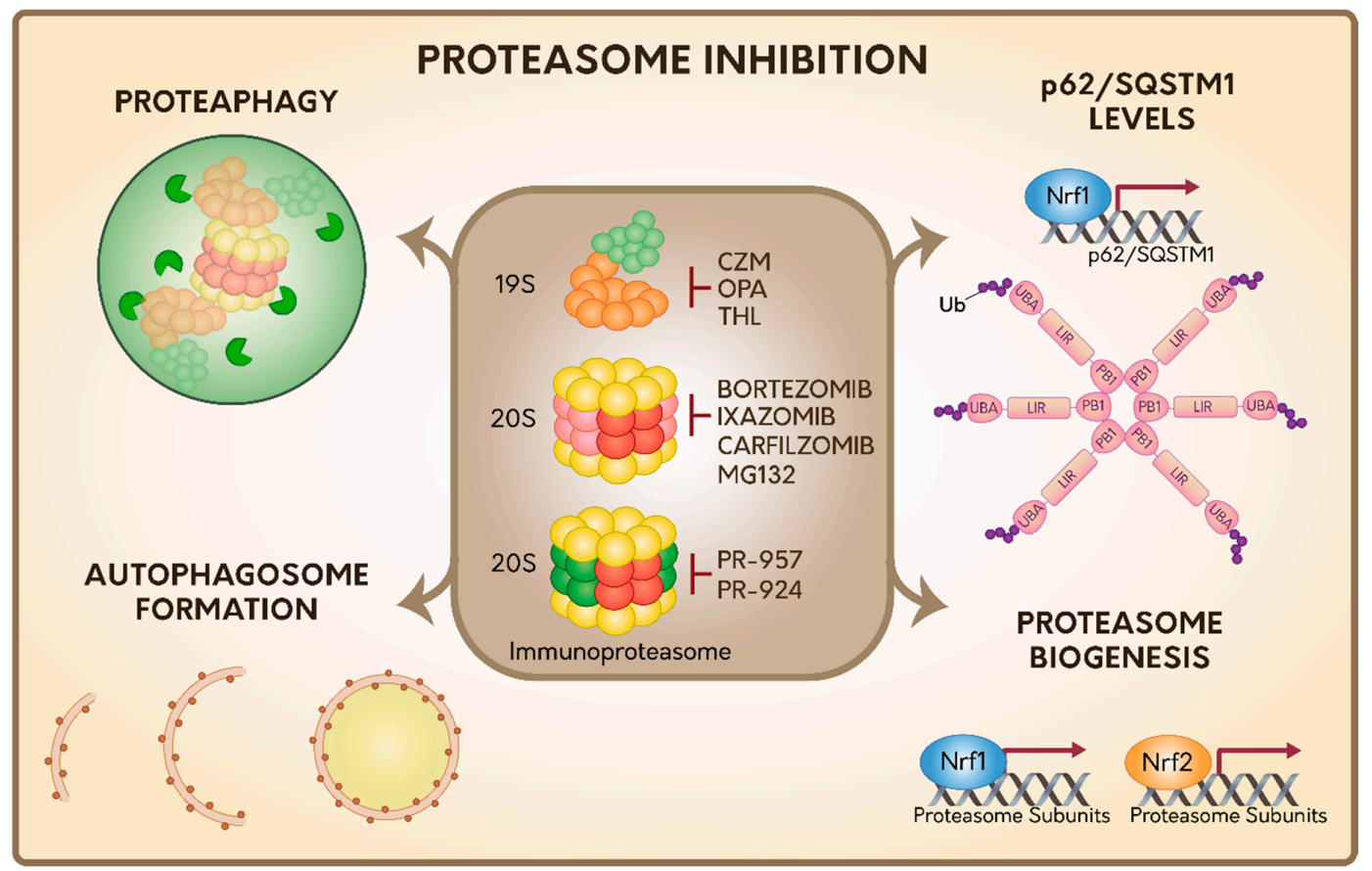

Figure 2. Summary of the cellular responses during proteasome inhibition. Several proteasome inhibitors have been described targeting $19 \mathrm{~S}$ RP, $20 \mathrm{~S}$ proteasome and immunoproteasome. In response to proteasome inhibition, several responses are activated specifically related with the $20 \mathrm{~S}$ proteasome, including the Autophagic-Lysosomal Pathway (ALP), proteaphagy, the transcriptional upregulation of the autophagy Ub receptor p62/SQSTM1, and proteasome genes, by Nrf1 and Nrf1/Nrf2 transcription factors, respectively. The activation of the autophagy $\mathrm{Ub}$ receptor p62/SQSTM1 is dependent on specific post-translational modifications based on ubiquitylation. However, it is still unknown which responses could be activated under the inhibition of 19S RP or immunoproteasome.

\subsection{Inhibitors of the DUB Rpn11 in the $19 S \mathrm{RP}$}

Capzimin (CZM) is the first-in-class inhibitor of 19S RP proteasome, which acts inhibiting the DUB Rpn11 of the 19S RP described above [129] (Figure 2). Rpn11 removes the polyubiquitin chains of the substrates prior to their entry and degradation in the 20S proteasome, also allowing the recycling of $\mathrm{Ub}$ molecules. Interestingly, CZM has been proven to be effective in several cancer cell lines, including those that are resistant to bortezomib. It triggers the inhibition of cell proliferation and the induction of ER stress and cell death [129]. Likewise, other two Rpn11 inhibitors have been reported [130,131]. For instance, O-phenanthroline (OPA), which triggers ER stress and cell death in multiple myeloma 
cells [130] and thiolutin (THL), an antibiotic compound derivate from Streptomyces [131] (Figure 2). All these inhibitors have a common phenotype in mammalian cells, which is the increase in the levels of polyubiquitylated proteins, confirming its key role in the clearance of proteasome substrates. In addition, recent findings indicate that levels of Rpn11 (mRNA and protein) are increased in a variety of tumor cell types $[130,132]$. Thus, downregulation or inhibition of Rpn11 is currently proposed as an attractive strategy against tumor growth. Whether these inhibitors could also be a good strategy in the treatment of inflammatory and autoimmune diseases has not yet been explored.

\section{Cellular Responses upon Proteasome Inhibition}

\subsection{Proteasome Inhibition Leads to Autophagic-Lysosomal Pathway Activation}

In addition to the UPS function, the Autophagic-Lysosomal Pathway (ALP) is responsible for approximately $10 \%-20 \%$ of the protein degradation [3], a mechanism mostly specialized in bulk degradation of substrates including protein aggregates or organelles in lysosomes such as mitochondria, endoplasmic reticulum, lipid droplets, among others [133]. This pathway is characterized by the biogenesis of an organelle enclosed by a double lipid bilayer named autophagosome, able to engulf the cytoplasmic constituents to later be fused with lysosomes, to form a hybrid organelle called autolysosome that mediates the degradation of the cargoes. The UPS and ALP regulate the cellular proteostasis, constituting a single network to achieve protein balance [134]. Even though these mechanisms have been studied separately, growing evidence indicates that they operate in an intimate cooperation [135] supported by the fact that UPS impairment is a strong trigger of ALP activation [136-140]. Recently, we reviewed the interplay between UPS and ALP with a focus on the molecular players that mediate their functional crosstalk, highlighting the Ub signal as the unifying factor in cellular proteostasis maintenance [141].

The experimental approaches to block proteasome function are frequently based on the use of pharmacological proteasome inhibitors that normally target the catalytic subunits in the 20S proteasome [136-140,142-145], overexpression of exogenous proteins that are prone to aggregate $[138,144,146-150]$, and more recently the use of genetic tools to modify the gene expression of specific subunits in the proteasome $[144,150]$.

Early evidences showed that pharmacological proteasome inhibitors such as lactacystin and MG115 were potent inducers of ALP in neuronal cells. This was evidenced by the increase in autophagosome structures in ultrastructural studies and in positive structures with cathepsin D and ubiquitylated proteins $[136,137]$, a phenotype that was observed even under low dose exposure, but in a chronic form [136]. In later studies, it was demonstrated that treatment with several proteasome inhibitors such as ALLN [138], MG132 [138-140], and bortezomib [139,143-145] were able to increase LC3-II levels in different cell types. LC3-II corresponds to the lipidated form of LC3 (also named Microtubule-associated protein light chain 3 (MAP1LC3)), corresponding to the orthologous protein ATG8 in yeast. LC3-II/ATG8 is a protein covalently conjugated to phosphatidylethanolamine (PE) on autophagosomal membranes, a classical marker of autophagosomes [151,152]. Moreover, bortezomib upregulates the mRNA levels of LC3 [143] and of ATG5 and ATG7 [144], two key autophagy proteins involved in the LC3 lipidation. In addition, it was reported that proteasome inhibitors favor the activation of the transcription factor EB (TFEB), promoting its nuclear shuttling [153] together with an increase in its stability [154]. TFEB is currently considered as a master regulator of the lysosomal biogenesis and autophagy, because it coordinates the expression of the CLEAR network (Coordinated Lysosomal Expression and Regulation), which is composed of at least 471 targets, including a battery of many lysosomal and ATG genes [155-157].

On the other hand, overexpression of exogenous proteins prone to aggregate such as the ectopic expression of Huntingtin (Htt) with polyQ repeats (polyQ-Htt) [146] or the mutant superoxide dismutase 1 (SOD1) [147] resulted in the impairment of the proteasome function. This is due to allosteric inhibition of the $20 \mathrm{~S}$ proteasome by the oligomers, which in many cases form inclusion bodies, 
which act as a naturally occurring proteasome inhibition process. Interestingly, polyQ-Htt aggregates induce autophagosome formation demonstrated by conversion of LC3-I to LC3-II [149], increase in the number of LC3-positive structures [138,149] and upregulation of ALP genes [148,149]. Likewise, mutant SOD1 enhanced the conversion of LC3-I to LC3-II in neuronal cells [158]. In agreement with these findings, classical pharmacological inhibitors of ALP cause the accumulation of PolyQ-Htt $[148,149,159]$ and mutant SOD1 aggregates [160]. All these together suggest that ALP is activated as an attempt by the cells to reduce the toxicity of these mutant proteins.

Moreover, inhibition of the $20 \mathrm{~S}$ proteasome by the silencing of its $\beta 5$ subunit or triple silencing of $\beta 1, \beta 2$, and $\beta 5$ subunits in its proteolytic core, lead to the upregulation in ATG5 and ATG7 mRNA levels, key genes implicated in the lipidation of LC3-II [144]. In addition, depletion of Rpn10 and Rpn13, two of the receptors that participate in the recognition of polyubiquitylated substrates in the 19S RP cause strong activation of ALP, explaining how these cells survive the lack of these key proteins [150].

Together, this indicates that inhibition of the proteasome activity either by pharmacological inhibitors, protein aggregates or genetic tools designed to modify the expression of specific subunits of the proteasome, lead to the activation of the ALP system as a response to maintain the cellular proteostasis (Figure 2).

\subsection{Inclusion Body Formation and Associated-Proteins under Proteasome Inhibition}

Under treatment with proteasome inhibitors several proteins are accumulated forming protein aggregates. Once formed, aggregates accumulate forming inclusion bodies [161], which have been proposed could end up triggering side-effects during long term proteasome inhibition similar to the ones observed with the expression of pathogenic mutant proteins [162,163].

Different types of inclusion bodies have been identified in mammalian cells including the aggresomes [161] and stress granules (SGs) [164]. Initially, it was believed that protein aggregates were diffusing within cells, however it is currently accepted that the aggresome is the result of a coordinated retrograde transport of aggregates through microtubules in a dynein-dependent manner $[161,165,166]$. Aggresomes are specifically located at the perinuclear region near to the microtubule-organizing center (MTOC), where they seem to play a protective role when cells face proteotoxic stress by proteasomal inhibition. Aggresome formation is coordinated with the transport of autophagosomes and lysosomes to the same location to facilitate protein clearance $[137,138]$. On the other hand, it has been demonstrated that SGs are formed in cancer cells in response to bortezomib treatment, where they seem to promote tumor cell survival due to an inhibition in the degradation of mRNAs that encode key survival proteins [167]. Interestingly, these two types of inclusion bodies have been connected with p62/Sequestosome 1 (SQSTM1), a protein that colocalizes with both structures [168-170].

p62/SQSTM1 was the first mammalian autophagic Ubreceptor discovered [171-173]. It consists of a multi-domain protein with several protein-protein interaction motifs, which are key in its function. Its Ub-associated domain (UBA) interacts with the Ub-chains attached to the substrates [171,174], its Phox and Bem1 domain 1 (PB1) domain play a crucial role in its oligomerization and in its function as an $\mathrm{Ub}$ receptor [172,175]. Its LC3-interacting region (LIR) domain mediates binding to LC3 and Gamma-aminobutyric acid receptor-associated protein (GABARAP) subfamily proteins, which is a crucial step for its association to autophagosome membrane and delivery of the cargo for degradation $[133,172,173,176]$ (Figure 2).

Interestingly, several lines of evidence indicate that p62/SQSTM1 is able to sense proteasome inhibition. In particular, mRNA and protein levels of p62/SQSTM1 are upregulated upon expression of polyQ Htt [177], which impairs proteasome activity, as we mentioned before [146]. Similar results are found on pharmacological inhibition of the proteasome in Drosophila [178] and in mammalian cells [145,179-183]. In addition, it was found that bortezomib was able to increase a rapid and selective up-regulation of p62/SQSTM1 through the transcription factor Nuclear respiratory factor 1 (Nrf1) involved in de novo synthesis of the proteasome [183,184] (Figure 2). Moreover, these authors found that after a prolonged exposure to proteasome inhibitors, several ATG genes and autophagy Ub 
receptors were upregulated, which explains the activation of ALP pathway upon these treatments [183]. Interestingly, the rapid induction in the expression of p62/SQSTM1 upon proteasomal inhibition seems to be independent of other transcription factors previously reported such as Forkhead box O3 (FoxO3), phospho- Eukaryotic Initiation Factor 2 p-(eIF2 $\alpha$ ), Nuclear factor erythroid 2 (Nrf2), NF-kB: Nuclear Factor kappa B (NF-kB), and TFEB [183]. Finally, recent reports have shown that proteasome inhibition by MG132 increases the ubiquitylation state in p62/SQSTM1 [182]. In a similar manner, bortezomib increases the ubiquitylation of p62/SQSTM1 in the K420 residue, located within its UBA domain, increasing its function as an autophagy $\mathrm{Ub}$ receptor [145] (Figure 2). These findings strongly suggest that post-translational modifications (PTMs) in p62/SQSTM1 could act as another powerful attractive strategy that mediates the interplay between proteasome inhibition and ALP activation.

\subsection{Proteasome Inhibition Induces Proteaphagy}

The abundance and quality of the proteasome is finely regulated by the recent discovery of a process called proteaphagy, a conserved mechanism from plants to humans [185-187]. Proteaphagy is the process by which inactive and aged proteasomes are eliminated within cells through ALP [188]. Initially, it was found that the $20 \mathrm{~S}$ proteasome accumulates within lysosomes in rat liver cells when they were treated with nutrient starvation or leupeptin, a strong inhibitor of lysosome proteases [189]. In addition to this report, a proteomic study revealed the presence of $26 \mathrm{~S}$ proteasome subunits in autophagosome enriched fractions [190]. Therefore, these findings gave the first idea that the 20S and $26 \mathrm{~S}$ proteasome could be degraded by ALP (Figure 2).

Studies in Arabidopsis thaliana gave the first confirmation about this hypothesis and named this mechanism as proteaphagy [186]. Activation of ALP in Arabidopsis with nitrogen deprivation or MG132 showed the proteasome in autophagic bodies decorated with ATG8 [191]. Moreover, it was found that proteaphagy induced by MG132 is a process dependent on Rpn10 [185]. Rpn10 is found as an intrinsic $\mathrm{Ub}$ receptor of the 19S RP, or as a cytosolic protein within cells [32,192,193]. The cytosolic pool can simultaneously bind both, ATG8 and $\mathrm{Ub}$, acting as a selective autophagy receptor that targets inactive and ubiquitylated 26S proteasomes to autophagosomes [185]. Interestingly, levels of Rpn10 increased by MG132 treatment, probably due to its strong association to the $26 \mathrm{~S}$ proteasome, a result that was reproduced with the inhibition of the proteasome by bacterial infection [194]. All this suggests that proteaphagy is activated to eliminate inactive proteasome, which could help to reduce a toxic scenario during cellular stress.

Later studies in yeast demonstrated that MG132 could also activate proteaphagy, but using a different autophagy $\mathrm{Ub}$ receptor named Cue5 [186]. In addition, nitrogen deprivation also induced-proteaphagy in yeast, but few aspects of this pathway are currently known [195,196].

Proteaphagy in mammalian cells has been recently discovered [187], as a process dependent on the autophagy $\mathrm{Ub}$ receptor p62/SQSTM1 during starvation, which mediates the recognition of the ubiquitylated proteasome subunits [187]. To date, nothing yet is known about the role of proteaphagy under MG132 treatment in mammalian cells. Considering the fast and specific upregulation of p62/SQSTM1 upon proteasome inhibition, it is a good candidate to be explored.

\subsection{Proteasome Inhibition Induces Proteasome Biogenesis Dependent on Nrf1 and Nrf2 Transcription Factors}

Each time the proteasome function is inhibited, cells respond activating de novo proteasome synthesis through the upregulation in the expression of specific genes, encoding subunits of the $20 \mathrm{~S}$ proteasome or the 19S RP. This proteasome recovery mechanism is highly conserved between Drosophila [178] and mammalian cells $[91,197]$ and relies on the function of the transcription factor Nrf1 [184] (Figure 2). Nrf1 is an endoplasmic reticulum (ER) transmembrane protein that, under normal conditions, is subjected to ER-associated degradation (ERAD) [198]. Proteasome inhibition stabilizes Nrf1 on the ER membrane, where it gets cleaved by the DNA Damage Inducible 1 Homolog 2 (DDI-2) protease, resulting in the release of a proteolytic fragment of Nrf1 from the ER into the nucleus activating the transcription of proteasome subunit genes [199]. Thus, activation of Nrf1 in 
response to proteasome inhibition, constitutes a mechanism of resistance in cancer treatment [200]. Recently, it was reported that Nrf1 stability is also regulated by O-linked $\mathrm{N}$-acetylglucosamine $(\mathrm{O}-\mathrm{GlcNAc})$ modifications in serine or threonine residues by the O-linked $\mathrm{N}$-acetylglucosamine transferase (OGT) [201], an enzyme that is highly active in many types of cancer [202]. Interestingly, nuclear Nrf1 interacts with Beta-Transducin Repeat Containing E3 ligase $(\beta-\operatorname{TrCP})$, an E3 responsible for its ubiquitylation and proteasome degradation, which in turn leads to the reduction in de novo proteasome synthesis $[203,204]$. Interestingly, when Nrf1 is modified by O-GlcNAc modifications, it is unable to bind to $\beta$-TrCP, which explains why high OGT activity correlates with high levels of both, Nrf1 and proteasome [201].

In addition, the Nrf2 transcription factor, which is found in very low levels under normal conditions due to its rapid degradation through the proteasome is highly upregulated under oxidative stress and other stress conditions [205]. Once in the nucleus, Nrf2 promotes the synthesis of several proteins with antioxidant properties through common elements of response named Antioxidant Responsive Elements (ARE), found in genes such as the glutamate cysteine ligase catalytic subunit (GCLC), glutathione peroxidase (GPX-1), heme oxygenase-1 (HO-1), and catalase [206,207]. Moreover, Nrf2 has also been implicated in xenobiotic stress, mitochondrial respiration, stem cell quiescence, mRNA translation, autophagy and unfolded protein response (UPR) [208-213]. Importantly, Nrf2 cooperates in the expression of $20 \mathrm{~S}$ proteasome and PA2 $2 \alpha \beta$ subunits helping to restore oxidative damage and cell viability [214-216] (Figure 2). In contrast, expression of the immunoproteasome is regulated by TNF- $\alpha$ and IFN- $\gamma$ in a mechanism totally independent of Nrf1 and Nrf2 [217]. Hence, different types of proteasome are differentially expressed in cells according to cellular conditions and functions.

Together these findings indicate that proteasome inhibitors by themselves are not a good strategy for treatment, highlighting the importance of combined therapies that incorporate the role of newly-synthesized proteasome and its assembly. Blocking de novo proteasome synthesis by the regulation of Nrf1 stability, or by affecting Nrf2/ARE have recently been proposed as an interesting alternative strategy [218].

\section{Role of UPR and ER Stress in ALP Activation During Proteasome Inhibition}

Several studies have indicated that proteasome disruption either by pharmacological inhibitors $[139,143]$ or by proteins prone to aggregate $[149,219]$ leads to ER stress. Proteasome collaborates actively in ER quality control through the proteolysis of unfolded proteins in the lumen of the ER, acting as an important player in ERAD. Briefly, sophisticated machinery selects unfolded proteins in the lumen of the ER, by the recognition of specific branching of sugars that deliver these proteins back to the cytosol by retrotranslocation. In the cytosol, retrotranslocated proteins are polyubiquitylated and extracted from the ER membrane, where they are finally targeted to the proteasome for degradation [220]. Thus, proteasome inhibition increases the levels of unfolded proteins in the ER, a condition referred to as ER stress.

Cells deal with the accumulation of unfolded proteins with the activation of the UPR, involving the induction of molecular chaperones, translation attenuation, and upregulation of ERAD activity, all to avoid cell death [221]. Three different ER stress transducers in mammalian cells have been described called, Protein kinase R like endoplasmic reticulum kinase (PERK), Inositol-requiring enzyme 1 (IRE1), and Activating Transcription Factor 6 (ATF6), which sense the presence of unfolded proteins in the ER lumen and transduce signals to the cytoplasm and the nucleus [222,223]. PERK activation leads to the phosphorylation of the $\alpha$ subunit of the translation initiation factor, eIF $2 \alpha$, which inhibits the assembly of the $80 \mathrm{~S}$ ribosome and inhibits the global protein synthesis [224,225], providing time to cells to implement the reprogramming of the transcriptome. Activation of IRE1 and ATF6 promotes the transcription of UPR target genes. IRE1 is an ER resident transmembrane protein with endoribonuclease/kinase activity, which facilitates the cytoplasmic splicing of X-box binding protein 1 (XBP1) mRNA, generating the active form of the XBP1 transcription factor, named 
XBP1s (spliced) [226,227]. XBP1s enhances the expression of UPR genes involved in protein quality control, disulfide linkage and ERAD pathway components [226,228,229]. ATF6 is a membrane-bound transcription factor localized in the ER that serves as a sensor of ER stress as well as a transcriptional activator of UPR target genes. ATF6 undergoes proteolytic cleavage in response to ER stress, whereas its $\mathrm{N}$-terminal fragment is translocated to the nucleus and increases the expression of a network of genes, including ER chaperones such as binding-immunoglobulin protein (BiP)/Glucose-Regulated Protein, $78 \mathrm{kDa}$ (GRP78), and ERAD pathway components [230,231].

Interestingly, it is known that autophagosome formation is accelerated in the cells under ER stress [232]. In fact, early studies demonstrated that the only UPR signaling responsible for autophagosome formation under ER stress was IRE1 [232]. Moreover, the authors demonstrated that, in IRE1-deficient cells, the activation in the induction of autophagosome structures by nutrient starvation was perfectly normal, suggesting a specific mechanism for ALP induction during ER stress. In agreement with these findings, activation of ALP by MG132 and bortezomib was suppressed upon knock down or gene deletion of IRE1 [139]. However, other findings with protein aggregates as triggers of ER stress have contradicted this conclusion. For instance, activation of ALP with the ectopic expression of polyQ-Htt is abolished by PERK signaling pathway disruption [149]. Similar results have been observed with the expression of a protein prone to aggregate in ER Dysferlin L1341P [233] or in cells expressing eIF2 $\alpha$ mutant in the PERK phosphorylation site, treated with the proteasomal inhibitors bortezomib and NPI-0052 [144].

Together, this indicates that UPR signaling pathways, specifically IRE1 and PERK are involved in ALP activation during ER stress. However, how these signaling pathways mediate ALP activation is not well understood. New insights were recently found through a microarray analysis in the presence of tunicamycin, but not with proteasome inhibitors. The authors confirmed that IRE1 and PERK were required for the upregulation of transcripts of several autophagy related genes, including the autophagy $\mathrm{Ub}$ receptors p62/SQSTM1, Neighbor of BRCA1 gene 1 (NBR1), and BCL2 Interacting Protein 3 Like (BNIP3L)/ NIP-3-Like Protein X (NIX), that upon tunicamycin treatment [234], delivered cargoes to the autophagosomes by binding with LC3 through the LIR motif [235]. Consistent with these findings, it was previously found that treatment of neuronal cells with MG132, lactacystin or PSI increased the transcript of p62/SQSTM1 [179] as well as its homologue in flies [236].

Altogether, in vitro and in vivo studies indicate that proteasome inhibition activates ALP by a mechanism that involves IRE1 and PERK signaling pathways, highlighting the crucial role of ER in autophagosome formation. However, further systematic studies oriented at clarifying the link between proteasome inhibition, UPR signaling, and ALP activation are needed, considering the variety of proteasome particles and their regulators.

\section{Role of DUBs in ALP Activation During Proteasome Inhibition}

As was mentioned previously, an important regulatory step for efficient degradation through the $20 \mathrm{~S}$ proteasome is the deubiquityation of the substrates. However, in addition to this function, it has been proposed that USP14 and Rpn11 contribute to the interplay between UPS and ALP. USP14 activity regulates ALP because it mediates the deubiquitylation of Beclin1, a key step that promotes its binding to its partners ATG14L and UVRAG enhancing ALP function under normal scenarios [237]. When USP14 function is pharmacologically inhibited, proteasome activity is highly activated [39-41]. Interestingly, inhibition of USP14 also has an impact on ALP function dependent on the cell type. In H4 neuroglioma cells, USP14 inhibition causes an upregulation of autophagy [237]. In contrast, in Hek-293 the opposite phenotype is observed [41]. Regardless of this difference, it highlights a close interplay between UPS and ALP mediated by USP14 activity.

Another interesting DUB implicated in this interplay is Rpn11. Under inhibition of the proteasome, Rpn11 cleaves the ubiquitylated substrates in a non-canonical manner releasing free $\mathrm{K} 63-\mathrm{Ub}$ chains to the cytosol [238]. Interestingly, it was proposed that free cytosolic K63-Ub chains activate the clearance of protein aggregates by ALP dependent on Histone deacetylase 6 (HDAC6) [239,240]. K63-Ub chains 
trigger the interaction of HDAC6 with dynein motors allowing the efficient transport of aggregates along the microtubules to the MTOC. This transport seems to be critical to relocate these aggregates in the aggresome at the perinuclear region, where ALP takes place [241]. Moreover, binding of K63-Ub chains to HDAC6 favors the deacetylation of the cytoplasmic protein cortactin, which facilitates the assembly of the F-actin network, which is also necessary for ALP function [242,243].

\section{Concluding Remarks and Perspectives}

We have summarized the different types of proteasome particles present in mammalian cells, describing the most common regulatory mechanisms for proteasome regulation and the cellular responses upon proteasome inhibition (Figure 2). Due to the several side effects described for proteasome inhibitors, it is important to search for new drugs with different specific targets. One interesting drug is MLN4924, currently in phase I of clinical trials, an inhibitor of the CRLs subfamily of E3 RING ligases that abolishes the degradation of $20 \%$ of all cellular proteins and that has showed few side effects in mice. This strategy could also be extended in the future to the development of novel RING/HECT/U-box E3 ligases inhibitors with special focus on Not4, SNEV, and UBE3A, E3 ligases directly implicated in the control of proteasome assembly and function [244,245]. Finally, the crucial role of ER stress and UPR signaling pathways and the role of DUBs in ALP activation are highlighted as the major players that contribute to cellular adaptation upon proteasome inhibition.

Author Contributions: Conceptualization, N.A. and H.B.; writing-original draft preparation, N.A., H.B., A.S. and P.B.; writing - review and editing, A.S. and P.B.; funding acquisition, P.B.

Funding: This work was funded by Fondo Nacional de Desarrollo Científico y Tecnológico of Chile (FONDECYT; http://www.conicyt.cl/fondecyt) No. 1171649 to PVB and the Comisión Nacional de Investigación Científica y tecnológica (CONICYT) including Basal Programme No. AFB-170005 to PVB and AS and CONICYT PIA No. 172066 to PVB.

Acknowledgments: We thank Sergio Hernandez for the graphic design of the figures and Francisca Barake for critically reading the manuscript.

Conflicts of Interest: The authors declare no conflict of interest.

$\begin{array}{ll}\text { Abbreviations } \\ \text { ARE } & \text { Antioxidant responsive elements } \\ \text { ALP } & \text { Autophagic-Lysosomal Pathway } \\ \text { ATF6 } & \text { Activating Transcription Factor 6 } \\ \text { ATG } & \text { Autophagy related protein } \\ \text { Bip } & \text { Binding-Immunoglobulin Protein } \\ \text { BNIP3L } & \text { BCL2 Interacting Protein 3 Like } \\ \beta \text {-TrCP } & \text { Beta-Transducin Repeat Containing E3 Ubiquitin Protein Ligase } \\ \text { CZM } & \text { Capzimin } \\ \text { CLEAR } & \text { Coordinated Lysosomal Expression and Regulation } \\ \text { CRLs } & \text { Cullin-containing RING-finger ligases } \\ \text { CUE5 } & \text { Coupling of ubiquitin to ER degradation } \\ \text { DDI-2 } & \text { DNA Damage Inducible 1 Homolog 2 } \\ \text { DUBs } & \text { Deubiquitinase enzymes } \\ \text { EIF2 } \alpha & \text { Eukaryotic Initiation Factor 2 alpha } \\ \text { ER } & \text { Endoplasmic Reticulum } \\ \text { ERAD } & \text { ER-associated degradation } \\ \text { FDA } & \text { Food and Drug Administration } \\ \text { FoxO3 } & \text { Forkhead box O3 } \\ \text { GABARAP } & \text { Gamma-aminobutyric acid receptor-associated protein } \\ \text { GCLC } & \text { Glutamate cysteine ligase catalytic subunit } \\ \text { GPX-1 } & \text { Glutathione peroxidase 1 } \\ \text { GRP-78 } & \text { Glucose-Regulated Protein, 78kDa }\end{array}$




\begin{tabular}{|c|c|}
\hline HECT & Homologous to E6-AP carboxy terminus \\
\hline HDAC6 & Histone deacetylase 6 \\
\hline $\mathrm{HO}-1$ & Heme oxygenase- 1 \\
\hline Htt & Huntingtin \\
\hline IBD & Inflammatory bowel disease \\
\hline IRE1 & Inositol-requiring enzyme 1 \\
\hline LIR & LC3-interacting region \\
\hline MHC & Major histocompatibility complex \\
\hline MAPLC3 & Microtubule-associated protein light chain 3 \\
\hline MTOC & Microtubule-organizing center \\
\hline NBR1 & Neighbor of BRCA1 gene \\
\hline NF- $\kappa \mathrm{B}$ & Nuclear Factor kappa B \\
\hline NIX & NIP-3-Like Protein $X$ \\
\hline Nrf1 & Nuclear respiratory factor 1 \\
\hline Nrf2 & Nuclear factor erythroid 2 \\
\hline O-GlcNAc & O-linked N-acetylglucosamine \\
\hline OGT & O-linked $\mathrm{N}$-acetylglucosamine transferase \\
\hline OPA & O-phenanthroline \\
\hline PA & Proteasome activator \\
\hline PB1 & Phox and Bem 1 domain \\
\hline PE & Phosphatidylethanolamine \\
\hline PERK & Protein kinase $\mathrm{R}$ like endoplasmic reticulum kinase \\
\hline PI & Proteasome inhibitor \\
\hline PolyQ-Htt & Htt with polyQ repeats \\
\hline PTMs & Post-translational modifications \\
\hline RING & Really interesting new gene \\
\hline $\mathrm{RP}$ & Regulatory Particle \\
\hline Rpn & Regulatory particle of non-ATPase subunit \\
\hline Rpt & Regulatory particle of triple-A subunit \\
\hline SG & Stress granules \\
\hline SQSTM1 & Sequestosome \\
\hline SOD1 & Superoxide dismutase 1 \\
\hline TFEB & Transcription factor EB \\
\hline THL & Thiolutin \\
\hline $\mathrm{Ub}$ & Ubiquitin \\
\hline UBA & Ub-associated domain \\
\hline UPS & Ubiquitin-Proteasome System \\
\hline USP14 & Ubiquitin specific protease 14 \\
\hline UVRAG & UV Radiation Resistance-Associated Gene Protein \\
\hline VCP & Valosin-containing protein \\
\hline XBP-1 & X-box binding protein 1 \\
\hline
\end{tabular}

\section{References}

1. Gidalevitz, T.; Prahlad, V.; Morimoto, R.I. The stress of protein misfolding: From single cells to multicellular organisms. Cold Spring Harb. Perspect. Biol. 2011, 3. [CrossRef] [PubMed]

2. Chiti, F; Dobson, C.M. Protein misfolding, amyloid formation, and human disease: A summary of progress over the last decade. Annu. Rev. Biochem. 2017, 86, 27-68. [CrossRef] [PubMed]

3. Kwon, Y.T.; Ciechanover, A. The Ubiquitin Code in the Ubiquitin-Proteasome System and Autophagy. Trends Biochem. Sci. 2017, 42, 873-886. [CrossRef] [PubMed]

4. Collins, G.A.; Goldberg, A.L. The logic of the $26 S$ proteasome. Cell 2017, 169, 792-806. [CrossRef] [PubMed]

5. Ciechanover, A.; Kwon, Y.T. Degradation of misfolded proteins in neurodegenerative diseases: Therapeutic targets and strategies. Exp. Mol. Med. 2015, 47, e147. [CrossRef] [PubMed]

6. Yu, H.; Matouschek, A. Recognition of client proteins by the proteasome. Annu. Rev. Biophys. 2017, 46, 149-173. [CrossRef] 
7. Chen, D.; Dou, Q.P. The ubiquitin-proteasome system as a prospective molecular target for cancer treatment and prevention. Curr. Protein Pept. Sci. 2010, 11, 459-470. [CrossRef]

8. Ogorevc, E.; Schiffrer, E.S.; Sosič, I.; Gobec, S. A patent review of immunoproteasome inhibitors. Expert Opin. Ther. Pat. 2018, 28, 517-540. [CrossRef]

9. Coux, O.; Tanaka, K.; Goldberg, A.L. Structure and functions of the $20 \mathrm{~S}$ and $26 \mathrm{~S}$ proteasomes. Annu. Rev. Biochem. 1996, 65, 801-847. [CrossRef]

10. Rabl, J.; Smith, D.M.; Yu, Y.; Chang, S.C.; Goldberg, A.L.; Cheng, Y. Mechanism of gate opening in the $20 \mathrm{~S}$ proteasome by the proteasomal ATPases. Mol. Cell 2008, 30, 360-368. [CrossRef]

11. Bochtler, M.; Ditzel, L.; Groll, M.; Hartmann, C.; Huber, R. The Proteasome. Annu. Rev. Biophys. Biomol. Struct. 1999, 28, 295-317. [CrossRef] [PubMed]

12. Kish-Trier, E.; Hill, C.P. Structural biology of the proteasome. Annu. Rev. Biophys. 2013, 42, 29-49. [CrossRef] [PubMed]

13. Ortiz-Navarrete, V.; Seelig, A.; Gernold, M.; Frentzel, S.; Kloetzel, P.M.; Hämmerling, G.J. Subunit of the "20S" proteasome (multicatalytic proteinase) encoded by the major histocompatibility complex. Nature 1991, 353, 662-664. [CrossRef] [PubMed]

14. Nandi, D.; Jiang, H.; Monaco, J.J. Identification of MECL-1 (LMP-10) as the third IFN-gamma-inducible proteasome subunit. J. Immunol. 1996, 156, 2361-2364. [PubMed]

15. Kaur, G.; Batra, S. Emerging role of immunoproteasomes in pathophysiology. Immunol. Cell Biol. 2016, 94, 812-820. [CrossRef] [PubMed]

16. Rock, K.L.; Goldberg, A.L. Degradation of cell proteins and the generation of MHC class I-presented peptides. Annu. Rev. Immunol. 1999, 17, 739-779. [CrossRef]

17. Ichikawa, H.T.; Conley, T.; Muchamuel, T.; Jiang, J.; Lee, S.; Owen, T.; Barnard, J.; Nevarez, S.; Goldman, B.I.; Kirk, C.J.; et al. Beneficial effect of novel proteasome inhibitors in murine lupus via dual inhibition of type I interferon and autoantibody-secreting cells. Arthritis Rheum. 2012, 64, 493-503. [CrossRef]

18. Moritz, K.E.; McCormack, N.M.; Abera, M.B.; Viollet, C.; Yauger, Y.J.; Sukumar, G.; Dalgard, C.L.; Burnett, B.G. The role of the immunoproteasome in interferon- $\gamma$-mediated microglial activation. Sci. Rep. 2017, 7, 9365. [CrossRef]

19. Murata, S.; Takahama, Y.; Kasahara, M.; Tanaka, K. The immunoproteasome and thymoproteasome: Functions, evolution and human disease. Nat. Immunol. 2018, 19, 923-931. [CrossRef]

20. Chu-Ping, M.; Vu, J.H.; Proske, R.J.; Slaughter, C.A.; DeMartino, G.N. Identification, purification, and characterization of a high molecular weight, ATP-dependent activator (PA700) of the $20 \mathrm{~S}$ proteasome. J. Biol. Chem. 1994, 269, 3539-3547.

21. Gorbea, C.; Taillandier, D.; Rechsteiner, M. Mapping subunit contacts in the regulatory complex of the $26 \mathrm{~S}$ proteasome. S2 and S5b form a tetramer with ATPase subunits S4 and S7. J. Biol. Chem. 2000, 275, 875-882. [CrossRef] [PubMed]

22. Hough, R.; Rechsteiner, M. Ubiquitin-lysozyme conjugates. Purification and susceptibility to proteolysis. J. Biol. Chem. 1986, 261, 2391-2399.

23. Dubiel, W.; Ferrell, K.; Pratt, G.; Rechsteiner, M. Subunit 4 of the $26 \mathrm{~S}$ protease is a member of a novel eukaryotic ATPase family. J. Biol. Chem. 1992, 267, 22699-22702. [PubMed]

24. Dubiel, W.; Rechsteiner, M. The 195 regulatory complex of the $26 \mathrm{~S}$ proteasome. In Intracellular Protein Decradation; Advances in molecular and cell biology; Elsevier: Amsterdam, The Netherlands, 1998; Volume 27, pp. 129-163.

25. Elsasser, S.; Chandler-Militello, D.; Müller, B.; Hanna, J.; Finley, D. Rad23 and Rpn10 serve as alternative ubiquitin receptors for the proteasome. J. Biol. Chem. 2004, 279, 26817-26822. [CrossRef] [PubMed]

26. Schreiner, P.; Chen, X.; Husnjak, K.; Randles, L.; Zhang, N.; Elsasser, S.; Finley, D.; Dikic, I.; Walters, K.J.; Groll, M. Ubiquitin docking at the proteasome through a novel pleckstrin-homology domain interaction. Nature 2008, 453, 548-552. [CrossRef] [PubMed]

27. Rosenzweig, R.; Bronner, V.; Zhang, D.; Fushman, D.; Glickman, M.H. Rpn1 and Rpn2 coordinate ubiquitin processing factors at proteasome. J. Biol. Chem. 2012, 287, 14659-14671. [CrossRef] [PubMed]

28. Bertolaet, B.L.; Clarke, D.J.; Wolff, M.; Watson, M.H.; Henze, M.; Divita, G.; Reed, S.I. UBA domains of DNA damage-inducible proteins interact with ubiquitin. Nat. Struct. Biol. 2001, 8, 417-422. [CrossRef]

29. Zhang, D.; Chen, T.; Ziv, I.; Rosenzweig, R.; Matiuhin, Y.; Bronner, V.; Glickman, M.H.; Fushman, D. Together, Rpn10 and Dsk2 can serve as a polyubiquitin chain-length sensor. Mol. Cell 2009, 36, 1018-1033. [CrossRef] 
30. Glickman, M.H.; Rubin, D.M.; Fu, H.; Larsen, C.N.; Coux, O.; Wefes, I.; Pfeifer, G.; Cjeka, Z.; Vierstra, R.; Baumeister, W.; et al. Functional analysis of the proteasome regulatory particle. Mol. Biol. Rep. 1999, 26, 21-28. [CrossRef]

31. Liu, C.W.; Millen, L.; Roman, T.B.; Xiong, H.; Gilbert, H.F.; Noiva, R.; DeMartino, G.N.; Thomas, P.J. Conformational remodeling of proteasomal substrates by PA700, the $19 \mathrm{~S}$ regulatory complex of the $26 \mathrm{~S}$ proteasome. J. Biol. Chem. 2002, 277, 26815-26820. [CrossRef]

32. Finley, D. Recognition and processing of ubiquitin-protein conjugates by the proteasome. Annu. Rev. Biochem. 2009, 78, 477-513. [CrossRef] [PubMed]

33. Yao, T.; Cohen, R.E. A cryptic protease couples deubiquitination and degradation by the proteasome. Nature 2002, 419, 403-407. [CrossRef]

34. Verma, R.; Aravind, L.; Oania, R.; McDonald, W.H.; Yates, J.R.; Koonin, E.V.; Deshaies, R.J. Role of Rpn11 metalloprotease in deubiquitination and degradation by the $26 \mathrm{~S}$ proteasome. Science 2002, 298, 611-615. [CrossRef]

35. Mevissen, T.E.T.; Komander, D. Mechanisms of deubiquitinase specificity and regulation. Annu. Rev. Biochem. 2017, 86, 159-192. [CrossRef]

36. Peth, A.; Besche, H.C.; Goldberg, A.L. Ubiquitinated proteins activate the proteasome by binding to Usp14/Ubp6, which causes 20S gate opening. Mol. Cell 2009, 36, 794-804. [CrossRef] [PubMed]

37. Lander, G.C.; Estrin, E.; Matyskiela, M.E.; Bashore, C.; Nogales, E.; Martin, A. Complete subunit architecture of the proteasome regulatory particle. Nature 2012, 482, 186-191. [CrossRef] [PubMed]

38. Hanna, J.; Hathaway, N.A.; Tone, Y.; Crosas, B.; Elsasser, S.; Kirkpatrick, D.S.; Leggett, D.S.; Gygi, S.P.; King, R.W.; Finley, D. Deubiquitinating enzyme Ubp6 functions noncatalytically to delay proteasomal degradation. Cell 2006, 127, 99-111. [CrossRef] [PubMed]

39. Lee, B.-H.; Lee, M.J.; Park, S.; Oh, D.-C.; Elsasser, S.; Chen, P.-C.; Gartner, C.; Dimova, N.; Hanna, J.; Gygi, S.P.; et al. Enhancement of proteasome activity by a small-molecule inhibitor of USP14. Nature 2010, 467, 179-184. [CrossRef]

40. Boselli, M.; Lee, B.-H.; Robert, J.; Prado, M.A.; Min, S.-W.; Cheng, C.; Silva, M.C.; Seong, C.; Elsasser, S.; Hatle, K.M.; et al. An inhibitor of the proteasomal deubiquitinating enzyme USP14 induces tau elimination in cultured neurons. J. Biol. Chem. 2017, 292, 19209-19225. [CrossRef]

41. Kim, E.; Park, S.; Lee, J.H.; Mun, J.Y.; Choi, W.H.; Yun, Y.; Lee, J.; Kim, J.H.; Kang, M.-J.; Lee, M.J. Dual function of USP14 deubiquitinase in cellular proteasomal activity and autophagic flux. Cell Rep. 2018, 24, 732-743. [CrossRef]

42. Huber, E.M.; Groll, M. The Mammalian Proteasome Activator PA28 Forms an Asymmetric $\alpha 4 \beta 3$ Complex. Structure 2017, 25, 1473-1480.e3. [CrossRef] [PubMed]

43. Wilk, S.; Chen, W.E.; Magnusson, R.P. Properties of the nuclear proteasome activator PA28gamma (REGgamma). Arch. Biochem. Biophys. 2000, 383, 265-271. [CrossRef] [PubMed]

44. Ma, C.P.; Slaughter, C.A.; DeMartino, G.N. Identification, purification, and characterization of a protein activator (PA28) of the $20 \mathrm{~S}$ proteasome (macropain). J. Biol. Chem. 1992, 267, 10515-10523. [PubMed]

45. Dubiel, W.; Pratt, G.; Ferrell, K.; Rechsteiner, M. Purification of an $11 \mathrm{~S}$ regulator of the multicatalytic protease. J. Biol. Chem. 1992, 267, 22369-22377.

46. Tanahashi, N.; Murakami, Y.; Minami, Y.; Shimbara, N.; Hendil, K.B.; Tanaka, K. Hybrid proteasomes. Induction by interferon-gamma and contribution to ATP-dependent proteolysis. J. Biol. Chem. 2000, 275, 14336-14345. [CrossRef]

47. Cascio, P.; Call, M.; Petre, B.M.; Walz, T.; Goldberg, A.L. Properties of the hybrid form of the 26S proteasome containing both $19 S$ and PA28 complexes. EMBO J. 2002, 21, 2636-2645. [CrossRef]

48. Ahn, J.Y.; Tanahashi, N.; Akiyama, K.; Hisamatsu, H.; Noda, C.; Tanaka, K.; Chung, C.H.; Shibmara, N.; Willy, P.J.; Mott, J.D. Primary structures of two homologous subunits of PA28, a gamma-interferon-inducible protein activator of the 20 S proteasome. FEBS Lett. 1995, 366, 37-42.

49. Jiang, H.; Monaco, J.J. Sequence and expression of mouse proteasome activator PA28 and the related autoantigen Ki. Immunogenetics 1997, 46, 93-98. [CrossRef]

50. Tanahashi, N.; Yokota, K.; Ahn, J.Y.; Chung, C.H.; Fujiwara, T.; Takahashi, E.; DeMartino, G.N.; Slaughter, C.A.; Toyonaga, T.; Yamamura, K.; et al. Molecular properties of the proteasome activator PA28 family proteins and gamma-interferon regulation. Genes. Cells 1997, 2, 195-211. [CrossRef] 
51. Raule, M.; Cerruti, F.; Benaroudj, N.; Migotti, R.; Kikuchi, J.; Bachi, A.; Navon, A.; Dittmar, G.; Cascio, P. PA28 $\alpha \beta$ reduces size and increases hydrophilicity of $20 \mathrm{~S}$ immunoproteasome peptide products. Chem. Biol. 2014, 21, 470-480. [CrossRef]

52. Pickering, A.M.; Koop, A.L.; Teoh, C.Y.; Ermak, G.; Grune, T.; Davies, K.J.A. The immunoproteasome, the $20 \mathrm{~S}$ proteasome and the PA28 $\alpha \beta$ proteasome regulator are oxidative-stress-adaptive proteolytic complexes. Biochem. J. 2010, 432, 585-594. [CrossRef] [PubMed]

53. Pickering, A.M.; Davies, K.J.A. Differential roles of proteasome and immunoproteasome regulators Pa28 $\alpha \beta$, Pa28 $\gamma$ and Pa200 in the degradation of oxidized proteins. Arch. Biochem. Biophys. 2012, 523, 181-190. [CrossRef] [PubMed]

54. Johnston-Carey, H.K.; Pomatto, L.C.D.; Davies, K.J.A. The Immunoproteasome in oxidative stress, aging, and disease. Crit. Rev. Biochem. Mol. Biol. 2015, 51, 268-281. [CrossRef] [PubMed]

55. Hernebring, M.; Fredriksson, Å.; Liljevald, M.; Cvijovic, M.; Norrman, K.; Wiseman, J.; Semb, H.; Nyström, T. Removal of damaged proteins during ES cell fate specification requires the proteasome activator PA28. Sci. Rep. 2013, 3, 1381. [CrossRef]

56. Otoda, T.; Takamura, T.; Misu, H.; Ota, T.; Murata, S.; Hayashi, H.; Takayama, H.; Kikuchi, A.; Kanamori, T.; Shima, K.R.; et al. Proteasome dysfunction mediates obesity-induced endoplasmic reticulum stress and insulin resistance in the liver. Diabetes 2013, 62, 811-824. [CrossRef] [PubMed]

57. Murata, S.; Kawahara, H.; Tohma, S.; Yamamoto, K.; Kasahara, M.; Nabeshima, Y.; Tanaka, K.; Chiba, T. Growth retardation in mice lacking the proteasome activator PA28gamma. J. Biol. Chem. 1999, 274, 38211-38215. [CrossRef] [PubMed]

58. Chen, X.; Barton, L.F.; Chi, Y.; Clurman, B.E.; Roberts, J.M. Ubiquitin-independent degradation of cell-cycle inhibitors by the REGgamma proteasome. Mol. Cell 2007, 26, 843-852. [CrossRef]

59. Levy-Barda, A.; Lerenthal, Y.; Davis, A.J.; Chung, Y.M.; Essers, J.; Shao, Z.; van Vliet, N.; Chen, D.J.; Hu, M.C.-T.; Kanaar, R.; et al. Involvement of the nuclear proteasome activator PA28 $\gamma$ in the cellular response to DNA double-strand breaks. Cell Cycle 2011, 10, 4300-4310. [CrossRef]

60. Zhang, Z.; Zhang, R. Proteasome activator PA28 gamma regulates p53 by enhancing its MDM2-mediated degradation. EMBO J. 2008, 27, 852-864. [CrossRef]

61. Baldin, V.; Militello, M.; Thomas, Y.; Doucet, C.; Fic, W.; Boireau, S.; Jariel-Encontre, I.; Piechaczyk, M.; Bertrand, E.; Tazi, J.; et al. A novel role for PA28gamma-proteasome in nuclear speckle organization and SR protein trafficking. Mol. Biol. Cell 2008, 19, 1706-1716. [CrossRef]

62. Zannini, L.; Lecis, D.; Buscemi, G.; Carlessi, L.; Gasparini, P.; Fontanella, E.; Lisanti, S.; Barton, L.; Delia, D. REGgamma proteasome activator is involved in the maintenance of chromosomal stability. Cell Cycle 2008, 7, 504-512. [CrossRef] [PubMed]

63. Barton, L.F.; Runnels, H.A.; Schell, T.D.; Cho, Y.; Gibbons, R.; Tevethia, S.S.; Deepe, G.S.; Monaco, J.J. Immune defects in 28-kDa proteasome activator gamma-deficient mice. J. Immunol. 2004, 172, 3948-3954. [CrossRef] [PubMed]

64. Vigneron, N.; Van den Eynde, B.J. Proteasome subtypes and regulators in the processing of antigenic peptides presented by class I molecules of the major histocompatibility complex. Biomolecules 2014, 4, 994-1025. [CrossRef] [PubMed]

65. Ustrell, V.; Hoffman, L.; Pratt, G.; Rechsteiner, M. PA200, a nuclear proteasome activator involved in DNA repair. EMBO J. 2002, 21, 3516-3525. [CrossRef] [PubMed]

66. Blickwedehl, J.; McEvoy, S.; Wong, I.; Kousis, P.; Clements, J.; Elliott, R.; Cresswell, P.; Liang, P.; Bangia, N. Proteasomes and proteasome activator $200 \mathrm{kDa}$ (PA200) accumulate on chromatin in response to ionizing radiation. Radiat. Res. 2007, 167, 663-674. [CrossRef] [PubMed]

67. Blickwedehl, J.; Agarwal, M.; Seong, C.; Pandita, R.K.; Melendy, T.; Sung, P.; Pandita, T.K.; Bangia, N. Role for proteasome activator PA200 and postglutamyl proteasome activity in genomic stability. Proc. Natl. Acad. Sci. USA 2008, 105, 16165-16170. [CrossRef] [PubMed]

68. Blickwedehl, J.; Olejniczak, S.; Cummings, R.; Sarvaiya, N.; Mantilla, A.; Chanan-Khan, A.; Pandita, T.K.; Schmidt, M.; Thompson, C.B.; Bangia, N. The proteasome activator PA200 regulates tumor cell responsiveness to glutamine and resistance to ionizing radiation. Mol. Cancer Res. 2012, 10, 937-944. [CrossRef]

69. Khor, B.; Bredemeyer, A.L.; Huang, C.-Y.; Turnbull, I.R.; Evans, R.; Maggi, L.B.; White, J.M.; Walker, L.M.; Carnes, K.; Hess, R.A.; et al. Proteasome activator PA200 is required for normal spermatogenesis. Mol. Cell. Biol. 2006, 26, 2999-3007. [CrossRef] 
70. Leggett, D.S.; Hanna, J.; Borodovsky, A.; Crosas, B.; Schmidt, M.; Baker, R.T.; Walz, T.; Ploegh, H.; Finley, D. Multiple associated proteins regulate proteasome structure and function. Mol. Cell 2002, 10, 495-507. [CrossRef]

71. Lehmann, A.; Niewienda, A.; Jechow, K.; Janek, K.; Enenkel, C. Ecm29 fulfils quality control functions in proteasome assembly. Mol. Cell 2010, 38, 879-888. [CrossRef]

72. Wang, X.; Yen, J.; Kaiser, P.; Huang, L. Regulation of the 26S proteasome complex during oxidative stress. Sci. Signal. 2010, 3, ra88. [CrossRef] [PubMed]

73. De La Mota-Peynado, A.; Lee, S.Y.-C.; Pierce, B.M.; Wani, P.; Singh, C.R.; Roelofs, J. The proteasome-associated protein Ecm29 inhibits proteasomal ATPase activity and in vivo protein degradation by the proteasome. J. Biol. Chem. 2013, 288, 29467-29481. [CrossRef] [PubMed]

74. Gorbea, C.; Pratt, G.; Ustrell, V.; Bell, R.; Sahasrabudhe, S.; Hughes, R.E.; Rechsteiner, M. A protein interaction network for Ecm 29 links the $26 \mathrm{~S}$ proteasome to molecular motors and endosomal components. J. Biol. Chem. 2010, 285, 31616-31633. [CrossRef] [PubMed]

75. Zaiss, D.M.W.; Standera, S.; Kloetzel, P.-M.; Sijts, A.J.A.M. PI31 is a modulator of proteasome formation and antigen processing. Proc. Natl. Acad. Sci. USA 2002, 99, 14344-14349. [CrossRef] [PubMed]

76. McCutchen-Maloney, S.L.; Matsuda, K.; Shimbara, N.; Binns, D.D.; Tanaka, K.; Slaughter, C.A.; DeMartino, G.N. cDNA cloning, expression, and functional characterization of PI31, a proline-rich inhibitor of the proteasome. J. Biol. Chem. 2000, 275, 18557-18565. [CrossRef] [PubMed]

77. Clemen, C.S.; Marko, M.; Strucksberg, K.-H.; Behrens, J.; Wittig, I.; Gärtner, L.; Winter, L.; Chevessier, F.; Matthias, J.; Türk, M.; et al. VCP and PSMF1: Antagonistic regulators of proteasome activity. Biochem. Biophys. Res. Commun. 2015, 463, 1210-1217. [CrossRef] [PubMed]

78. Jentsch, S.; Rumpf, S. Cdc48 (p97): A "molecular gearbox" in the ubiquitin pathway? Trends Biochem. Sci. 2007, 32, 6-11. [CrossRef]

79. Meyer, H.; Weihl, C.C. The VCP/p97 system at a glance: Connecting cellular function to disease pathogenesis. J. Cell Sci. 2014, 127, 3877-3883. [CrossRef]

80. Jacobson, A.D.; MacFadden, A.; Wu, Z.; Peng, J.; Liu, C.-W. Autoregulation of the $26 \mathrm{~S}$ proteasome by in situ ubiquitination. Mol. Biol. Cell 2014, 25, 1824-1835. [CrossRef]

81. Ventadour, S.; Jarzaguet, M.; Wing, S.S.; Chambon, C.; Combaret, L.; Béchet, D.; Attaix, D.; Taillandier, D. A new method of purification of proteasome substrates reveals polyubiquitination of $20 \mathrm{~S}$ proteasome subunits. J. Biol. Chem. 2007, 282, 5302-5309. [CrossRef]

82. Motosugi, R.; Murata, S. Dynamic regulation of proteasome expression. Front. Mol. Biosci. 2019, 6, 30. [CrossRef] [PubMed]

83. Cui, Z.; Scruggs, S.B.; Gilda, J.E.; Ping, P.; Gomes, A.V. Regulation of cardiac proteasomes by ubiquitination, SUMOylation, and beyond. J. Mol. Cell Cardiol. 2014, 71, 32-42. [CrossRef] [PubMed]

84. Fu, X.; Sokolova, V.; Webb, K.J.; Old, W.; Park, S. Ubiquitin-dependent switch during assembly of the proteasomal ATPases mediated by Not4 ubiquitin ligase. Proc. Natl. Acad. Sci. USA 2018, 115, 13246-13251. [CrossRef] [PubMed]

85. Panasenko, O.O.; Collart, M.A. Not4 E3 ligase contributes to proteasome assembly and functional integrity in part through Ecm29. Mol. Cell. Biol. 2011, 31, 1610-1623. [CrossRef] [PubMed]

86. Löscher, M.; Fortschegger, K.; Ritter, G.; Wostry, M.; Voglauer, R.; Schmid, J.A.; Watters, S.; Rivett, A.J.; Ajuh, P.; Lamond, A.I.; et al. Interaction of U-box E3 ligase SNEV with PSMB4, the beta7 subunit of the $20 \mathrm{~S}$ proteasome. Biochem. J. 2005, 388, 593-603. [CrossRef] [PubMed]

87. Martinez, A.; Ramirez, J.; Osinalde, N.; Arizmendi, J.M.; Mayor, U. Neuronal Proteomic Analysis of the Ubiquitinated Substrates of the Disease-Linked E3 Ligases Parkin and Ube3a. BioMed Res. Int. 2018, 2018, 3180413. [CrossRef] [PubMed]

88. Tomaić, V.; Banks, L. Angelman syndrome-associated ubiquitin ligase UBE3A/E6AP mutants interfere with the proteolytic activity of the proteasome. Cell Death Dis. 2015, 6, e1625. [CrossRef]

89. Jung, T.; Catalgol, B.; Grune, T. The proteasomal system. Mol. Asp. Med. 2009, 30, 191-296. [CrossRef]

90. Obeng, E.A.; Carlson, L.M.; Gutman, D.M.; Harrington, W.J.; Lee, K.P.; Boise, L.H. Proteasome inhibitors induce a terminal unfolded protein response in multiple myeloma cells. Blood 2006, 107, 4907-4916. [CrossRef]

91. Mitsiades, N.; Mitsiades, C.S.; Poulaki, V.; Chauhan, D.; Fanourakis, G.; Gu, X.; Bailey, C.; Joseph, M.; Libermann, T.A.; Treon, S.P.; et al. Molecular sequelae of proteasome inhibition in human multiple myeloma cells. Proc. Natl. Acad. Sci. USA 2002, 99, 14374-14379. [CrossRef] 
92. Yarde, D.N.; Oliveira, V.; Mathews, L.; Wang, X.; Villagra, A.; Boulware, D.; Shain, K.H.; Hazlehurst, L.A.; Alsina, M.; Chen, D.-T.; et al. Targeting the Fanconi anemia/BRCA pathway circumvents drug resistance in multiple myeloma. Cancer Res. 2009, 69, 9367-9375. [CrossRef]

93. Robak, P.; Drozdz, I.; Szemraj, J.; Robak, T. Drug resistance in multiple myeloma. Cancer Treat. Rev. 2018, 70, 199-208. [CrossRef] [PubMed]

94. Mohty, M.; Brissot, E.; Savani, B.N.; Gaugler, B. Effects of bortezomib on the immune system: A focus on immune regulation. Biol. Blood Marrow Transplant. 2013, 19, 1416-1420. [CrossRef] [PubMed]

95. Verbrugge, S.E.; Scheper, R.J.; Lems, W.F.; de Gruijl, T.D.; Jansen, G. Proteasome inhibitors as experimental therapeutics of autoimmune diseases. Arthritis Res. Ther. 2015, 17, 17. [CrossRef] [PubMed]

96. Alexander, T.; Cheng, Q.; Klotsche, J.; Khodadadi, L.; Waka, A.; Biesen, R.; Hoyer, B.F.; Burmester, G.R.; Radbruch, A.; Hiepe, F. Proteasome inhibition with bortezomib induces a therapeutically relevant depletion of plasma cells in SLE but does not target their precursors. Eur. J. Immunol. 2018, 48, 1573-1579. [CrossRef]

97. Chen, F.-T.; Liu, Y.-C.; Yang, C.-M.; Yang, C.-H. Anti-inflammatory effect of the proteasome inhibitor bortezomib on endotoxin-induced uveitis in rats. Investig. Ophthalmol. Vis. Sci. 2012, 53, 3682-3694. [CrossRef]

98. Chen, F.-T.; Yang, C.-M.; Yang, C.-H. The protective effects of the proteasome inhibitor bortezomib (velcade) on ischemia-reperfusion injury in the rat retina. PLoS ONE 2013, 8, e64262. [CrossRef] [PubMed]

99. Kisselev, A.F.; Goldberg, A.L. Proteasome inhibitors: From research tools to drug candidates. Chem. Biol. 2001, 8, 739-758. [CrossRef]

100. Tsubuki, S.; Saito, Y.; Tomioka, M.; Ito, H.; Kawashima, S. Differential inhibition of calpain and proteasome activities by peptidyl aldehydes of di-leucine and tri-leucine. J. Biochem. 1996, 119, 572-576. [CrossRef]

101. Guo, N.; Peng, Z. MG132, a proteasome inhibitor, induces apoptosis in tumor cells. Asia Pac. J. Clin. Oncol. 2013, 9, 6-11. [CrossRef]

102. Kane, R.C.; Bross, P.F.; Farrell, A.T.; Pazdur, R. Velcade: U.S. FDA approval for the treatment of multiple myeloma progressing on prior therapy. Oncologist 2003, 8, 508-513. [CrossRef] [PubMed]

103. Adams, J.; Palombella, V.J.; Sausville, E.A.; Johnson, J.; Destree, A.; Lazarus, D.D.; Maas, J.; Pien, C.S.; Prakash, S.; Elliott, P.J. Proteasome inhibitors: A novel class of potent and effective antitumor agents. Cancer Res. 1999, 59, 2615-2622.

104. Bennett, M.K.; Kirk, C.J. Development of proteasome inhibitors in oncology and autoimmune diseases. Curr. Opin. Drug Discov. Dev. 2008, 11, 616-625.

105. Argyriou, A.A.; Bruna, J.; Marmiroli, P.; Cavaletti, G. Chemotherapy-induced peripheral neurotoxicity (CIPN): An update. Crit. Rev. Oncol. Hematol. 2012, 82, 51-77. [CrossRef]

106. Muchtar, E.; Gertz, M.A.; Magen, H. A practical review on carfilzomib in multiple myeloma. Eur. J. Haematol. 2016, 96, 564-577. [CrossRef] [PubMed]

107. Demo, S.D.; Kirk, C.J.; Aujay, M.A.; Buchholz, T.J.; Dajee, M.; Ho, M.N.; Jiang, J.; Laidig, G.J.; Lewis, E.R.; Parlati, F.; et al. Antitumor activity of PR-171, a novel irreversible inhibitor of the proteasome. Cancer Res. 2007, 67, 6383-6391. [CrossRef]

108. Parlati, F.; Lee, S.J.; Aujay, M.; Suzuki, E.; Levitsky, K.; Lorens, J.B.; Micklem, D.R.; Ruurs, P.; Sylvain, C.; $\mathrm{Lu}, \mathrm{Y}$; , et al. Carfilzomib can induce tumor cell death through selective inhibition of the chymotrypsin-like activity of the proteasome. Blood 2009, 114, 3439-3447. [CrossRef]

109. Redic, K. Carfilzomib: A novel agent for multiple myeloma. J. Pharm. Pharmacol. 2013, 65, 1095-1106. [CrossRef]

110. Chauhan, D.; Tian, Z.; Zhou, B.; Kuhn, D.; Orlowski, R.; Raje, N.; Richardson, P.; Anderson, K.C. In vitro and in vivo selective antitumor activity of a novel orally bioavailable proteasome inhibitor MLN9708 against multiple myeloma cells. Clin. Cancer Res. 2011, 17, 5311-5321. [CrossRef]

111. Park, J.E.; Miller, Z.; Jun, Y.; Lee, W.; Kim, K.B. Next-generation proteasome inhibitors for cancer therapy. Transl. Res. 2018, 198,1-16. [CrossRef]

112. Merin, N.M.; Kelly, K.R. Clinical use of proteasome inhibitors in the treatment of multiple myeloma. Pharmaceuticals (Basel) 2014, 8, 1-20. [CrossRef] [PubMed]

113. Groll, M.; Huber, R.; Potts, B.C.M. Crystal structures of Salinosporamide A (NPI-0052) and B (NPI-0047) in complex with the $20 \mathrm{~S}$ proteasome reveal important consequences of beta-lactone ring opening and a mechanism for irreversible binding. J. Am. Chem. Soc. 2006, 128, 5136-5141. [CrossRef] [PubMed] 
114. Chauhan, D.; Singh, A.V.; Ciccarelli, B.; Richardson, P.G.; Palladino, M.A.; Anderson, K.C. Combination of novel proteasome inhibitor NPI-0052 and lenalidomide trigger in vitro and in vivo synergistic cytotoxicity in multiple myeloma. Blood 2010, 115, 834-845. [CrossRef] [PubMed]

115. Di, K.; Lloyd, G.K.; Abraham, V.; MacLaren, A.; Burrows, F.J.; Desjardins, A.; Trikha, M.; Bota, D.A. Marizomib activity as a single agent in malignant gliomas: Ability to cross the blood-brain barrier. Neuro-Oncology 2016, 18, 840-848. [CrossRef]

116. Yewdell, J.W. Immunoproteasomes: Regulating the regulator. Proc. Natl. Acad. Sci. USA 2005, 102, 9089-9090. [CrossRef] [PubMed]

117. Kuhn, D.J.; Orlowski, R.Z.; Bjorklund, C.C. Second generation proteasome inhibitors: Carfilzomib and immunoproteasome-specific inhibitors (IPSIs). Curr. Cancer Drug Targets 2011, 11, 285-295. [CrossRef] [PubMed]

118. Lee, W.; Kim, K.B. The immunoproteasome: An emerging therapeutic target. Curr. Top. Med. Chem. 2011, 11, 2923-2930. [CrossRef]

119. Basler, M.; Dajee, M.; Moll, C.; Groettrup, M.; Kirk, C.J. Prevention of experimental colitis by a selective inhibitor of the immunoproteasome. J. Immunol. 2010, 185, 634-641. [CrossRef]

120. Vasuri, F.; Capizzi, E.; Bellavista, E.; Mishto, M.; Santoro, A.; Fiorentino, M.; Capri, M.; Cescon, M.; Grazi, G.L.; Grigioni, W.F.; et al. Studies on immunoproteasome in human liver. Part I: Absence in fetuses, presence in normal subjects, and increased levels in chronic active hepatitis and cirrhosis. Biochem. Biophys. Res. Commun. 2010, 397, 301-306. [CrossRef]

121. Fitzpatrick, L.R.; Khare, V.; Small, J.S.; Koltun, W.A. Dextran sulfate sodium-induced colitis is associated with enhanced low molecular mass polypeptide 2 (LMP2) expression and is attenuated in LMP2 knockout mice. Dig. Dis. Sci. 2006, 51, 1269-1276. [CrossRef]

122. Fitzpatrick, L.R.; Small, J.S.; Poritz, L.S.; McKenna, K.J.; Koltun, W.A. Enhanced intestinal expression of the proteasome subunit low molecular mass polypeptide 2 in patients with inflammatory bowel disease. Dis. Colon Rectum 2007, 50, 337-350.e10. [CrossRef] [PubMed]

123. Visekruna, A.; Slavova, N.; Dullat, S.; Gröne, J.; Kroesen, A.-J.; Ritz, J.-P.; Buhr, H.-J.; Steinhoff, U. Expression of catalytic proteasome subunits in the gut of patients with Crohn's disease. Int. J. Colorectal Dis. 2009, 24, 1133-1139. [CrossRef]

124. Muchamuel, T.; Basler, M.; Aujay, M.A.; Suzuki, E.; Kalim, K.W.; Lauer, C.; Sylvain, C.; Ring, E.R.; Shields, J.; Jiang, J.; et al. A selective inhibitor of the immunoproteasome subunit LMP7 blocks cytokine production and attenuates progression of experimental arthritis. Nat. Med. 2009, 15, 781-787. [CrossRef] [PubMed]

125. Singh, A.V.; Bandi, M.; Aujay, M.A.; Kirk, C.J.; Hark, D.E.; Raje, N.; Chauhan, D.; Anderson, K.C. PR-924, a selective inhibitor of the immunoproteasome subunit LMP-7, blocks multiple myeloma cell growth both in vitro and in vivo. Br. J. Haematol. 2011, 152, 155-163. [CrossRef] [PubMed]

126. Niewerth, D.; van Meerloo, J.; Jansen, G.; Assaraf, Y.G.; Hendrickx, T.C.; Kirk, C.J.; Anderl, J.L.; Zweegman, S.; Kaspers, G.J.L.; Cloos, J. Anti-leukemic activity and mechanisms underlying resistance to the novel immunoproteasome inhibitor PR-924. Biochem. Pharmacol. 2014, 89, 43-51. [CrossRef]

127. Huber, E.M.; Basler, M.; Schwab, R.; Heinemeyer, W.; Kirk, C.J.; Groettrup, M.; Groll, M. Immuno- and constitutive proteasome crystal structures reveal differences in substrate and inhibitor specificity. Cell 2012, 148, 727-738. [CrossRef] [PubMed]

128. Ettari, R.; Zappalà, M.; Grasso, S.; Musolino, C.; Innao, V.; Allegra, A. Immunoproteasome-selective and non-selective inhibitors: A promising approach for the treatment of multiple myeloma. Pharmacol. Ther. 2018, 182, 176-192. [CrossRef]

129. Li, J.; Yakushi, T.; Parlati, F.; Mackinnon, A.L.; Perez, C.; Ma, Y.; Carter, K.P.; Colayco, S.; Magnuson, G.; Brown, B.; et al. Capzimin is a potent and specific inhibitor of proteasome isopeptidase Rpn11. Nat. Chem. Biol. 2017, 13, 486-493. [CrossRef]

130. Song, Y.; Li, S.; Ray, A.; Das, D.S.; Qi, J.; Samur, M.K.; Tai, Y.T.; Munshi, N.; Carrasco, R.D.; Chauhan, D.; et al. Blockade of deubiquitylating enzyme Rpn11 triggers apoptosis in multiple myeloma cells and overcomes bortezomib resistance. Oncogene 2017, 36, 5631-5638. [CrossRef]

131. Lauinger, L.; Li, J.; Shostak, A.; Cemel, I.A.; Ha, N.; Zhang, Y.; Merkl, P.E.; Obermeyer, S.; Stankovic-Valentin, N.; Schafmeier, T.; et al. Thiolutin is a zinc chelator that inhibits the Rpn11 and other JAMM metalloproteases. Nat. Chem. Biol. 2017, 13, 709-714. [CrossRef] 
132. Wang, C.-H.; Lu, S.-X.; Liu, L.-L.; Li, Y.; Yang, X.; He, Y.-F.; Chen, S.-L.; Cai, S.-H.; Wang, H.; Yun, J.-P. POH1 knockdown induces cancer cell apoptosis via p53 and bim. Neoplasia 2018, 20, 411-424. [CrossRef] [PubMed]

133. Cohen-Kaplan, V.; Livneh, I.; Avni, N.; Cohen-Rosenzweig, C.; Ciechanover, A. The ubiquitin-proteasome system and autophagy: Coordinated and independent activities. Int. J. Biochem. Cell Biol. 2016, 79, 403-418. [CrossRef] [PubMed]

134. Balch, W.E.; Morimoto, R.I.; Dillin, A.; Kelly, J.W. Adapting proteostasis for disease intervention. Science 2008, 319, 916-919. [CrossRef] [PubMed]

135. Korolchuk, V.I.; Menzies, F.M.; Rubinsztein, D.C. Mechanisms of cross-talk between the ubiquitin-proteasome and autophagy-lysosome systems. FEBS Lett. 2010, 584, 1393-1398. [CrossRef] [PubMed]

136. Ding, Q.; Dimayuga, E.; Martin, S.; Bruce-Keller, A.J.; Nukala, V.; Cuervo, A.M.; Keller, J.N. Characterization of chronic low-level proteasome inhibition on neural homeostasis. J. Neurochem. 2003, 86, 489-497. [CrossRef] [PubMed]

137. Rideout, H.J.; Lang-Rollin, I.; Stefanis, L. Involvement of macroautophagy in the dissolution of neuronal inclusions. Int. J. Biochem. Cell Biol. 2004, 36, 2551-2562. [CrossRef] [PubMed]

138. Iwata, A.; Riley, B.E.; Johnston, J.A.; Kopito, R.R. HDAC6 and microtubules are required for autophagic degradation of aggregated huntingtin. J. Biol. Chem. 2005, 280, 40282-40292. [CrossRef] [PubMed]

139. Ding, W.-X.; Ni, H.-M.; Gao, W.; Yoshimori, T.; Stolz, D.B.; Ron, D.; Yin, X.-M. Linking of autophagy to ubiquitin-proteasome system is important for the regulation of endoplasmic reticulum stress and cell viability. Am. J. Pathol. 2007, 171, 513-524. [CrossRef] [PubMed]

140. Lan, D.; Wang, W.; Zhuang, J.; Zhao, Z. Proteasome inhibitor-induced autophagy in PC12 cells overexpressing A53T mutant $\alpha$-synuclein. Mol. Med. Rep. 2015, 11, 1655-1660. [CrossRef] [PubMed]

141. Bustamante, H.A.; González, A.E.; Cerda-Troncoso, C.; Shaughnessy, R.; Otth, C.; Soza, A.; Burgos, P.V. Interplay Between the Autophagy-Lysosomal Pathway and the Ubiquitin-Proteasome System: A Target for Therapeutic Development in Alzheimer's Disease. Front. Cell. Neurosci. 2018, 12, 126. [CrossRef] [PubMed]

142. Rideout, H.J.; Stefanis, L. Proteasomal inhibition-induced inclusion formation and death in cortical neurons require transcription and ubiquitination. Mol. Cell. Neurosci. 2002, 21, 223-238. [CrossRef] [PubMed]

143. Milani, M.; Rzymski, T.; Mellor, H.R.; Pike, L.; Bottini, A.; Generali, D.; Harris, A.L. The role of ATF4 stabilization and autophagy in resistance of breast cancer cells treated with Bortezomib. Cancer Res. 2009, 69, 4415-4423. [CrossRef] [PubMed]

144. Zhu, K.; Dunner, K.; McConkey, D.J. Proteasome inhibitors activate autophagy as a cytoprotective response in human prostate cancer cells. Oncogene 2010, 29, 451-462. [CrossRef] [PubMed]

145. Peng, H.; Yang, J.; Li, G.; You, Q.; Han, W.; Li, T.; Gao, D.; Xie, X.; Lee, B.-H.; Du, J.; et al. Ubiquitylation of p62/sequestosome1 activates its autophagy receptor function and controls selective autophagy upon ubiquitin stress. Cell Res. 2017, 27, 657-674. [CrossRef] [PubMed]

146. Nishitoh, H.; Matsuzawa, A.; Tobiume, K.; Saegusa, K.; Takeda, K.; Inoue, K.; Hori, S.; Kakizuka, A.; Ichijo, H. ASK1 is essential for endoplasmic reticulum stress-induced neuronal cell death triggered by expanded polyglutamine repeats. Genes Dev. 2002, 16, 1345-1355. [CrossRef]

147. Urushitani, M.; Kurisu, J.; Tsukita, K.; Takahashi, R. Proteasomal inhibition by misfolded mutant superoxide dismutase 1 induces selective motor neuron death in familial amyotrophic lateral sclerosis. J. Neurochem. 2002, 83, 1030-1042. [CrossRef] [PubMed]

148. Qin, Z.-H.; Wang, Y.; Kegel, K.B.; Kazantsev, A.; Apostol, B.L.; Thompson, L.M.; Yoder, J.; Aronin, N.; DiFiglia, M. Autophagy regulates the processing of amino terminal huntingtin fragments. Hum. Mol. Genet. 2003, 12, 3231-3244. [CrossRef]

149. Kouroku, Y.; Fujita, E.; Tanida, I.; Ueno, T.; Isoai, A.; Kumagai, H.; Ogawa, S.; Kaufman, R.J.; Kominami, E.; Momoi, T. ER stress (PERK/eIF2alpha phosphorylation) mediates the polyglutamine-induced LC3 conversion, an essential step for autophagy formation. Cell Death Differ. 2007, 14, 230-239. [CrossRef]

150. Demishtein, A.; Fraiberg, M.; Berko, D.; Tirosh, B.; Elazar, Z.; Navon, A. SQSTM1/p62-mediated autophagy compensates for loss of proteasome polyubiquitin recruiting capacity. Autophagy 2017, 13, 1697-1708. [CrossRef]

151. Kabeya, Y.; Mizushima, N.; Yamamoto, A.; Oshitani-Okamoto, S.; Ohsumi, Y.; Yoshimori, T. LC3, GABARAP and GATE16 localize to autophagosomal membrane depending on form-II formation. J. Cell Sci. 2004, 117, 2805-2812. [CrossRef] 
152. Nakatogawa, H.; Ichimura, Y.; Ohsumi, Y. Atg8, a ubiquitin-like protein required for autophagosome formation, mediates membrane tethering and hemifusion. Cell 2007, 130, 165-178. [CrossRef] [PubMed]

153. Chen, L.; Wang, K.; Long, A.; Jia, L.; Zhang, Y.; Deng, H.; Li, Y.; Han, J.; Wang, Y. Fasting-induced hormonal regulation of lysosomal function. Cell Res. 2017, 27, 748-763. [CrossRef] [PubMed]

154. Sha, Y.; Rao, L.; Settembre, C.; Ballabio, A.; Eissa, N.T. STUB1 regulates TFEB-induced autophagy-lysosome pathway. EMBO J. 2017, 36, 2544-2552. [CrossRef]

155. Sardiello, M.; Palmieri, M.; di Ronza, A.; Medina, D.L.; Valenza, M.; Gennarino, V.A.; Di Malta, C.; Donaudy, F.; Embrione, V.; Polishchuk, R.S.; et al. A gene network regulating lysosomal biogenesis and function. Science 2009, 325, 473-477. [CrossRef] [PubMed]

156. Palmieri, M.; Impey, S.; Kang, H.; di Ronza, A.; Pelz, C.; Sardiello, M.; Ballabio, A. Characterization of the CLEAR network reveals an integrated control of cellular clearance pathways. Hum. Mol. Genet. 2011, 20, 3852-3866. [CrossRef] [PubMed]

157. Settembre, C.; Di Malta, C.; Polito, V.A.; Garcia Arencibia, M.; Vetrini, F.; Erdin, S.; Erdin, S.U.; Huynh, T.; Medina, D.; Colella, P.; et al. TFEB links autophagy to lysosomal biogenesis. Science 2011, 332, 1429-1433. [CrossRef] [PubMed]

158. Wei, Y. Autophagic induction of amyotrophic lateral sclerosis-linked $\mathrm{Cu} / \mathrm{Zn}$ superoxide dismutase $1 \mathrm{G} 93 \mathrm{~A}$ mutant in NSC34 cells. Neural Regen. Res. 2014, 9, 16-24. [CrossRef]

159. Ravikumar, B.; Duden, R.; Rubinsztein, D.C. Aggregate-prone proteins with polyglutamine and polyalanine expansions are degraded by autophagy. Hum. Mol. Genet. 2002, 11, 1107-1117. [CrossRef]

160. Kabuta, T.; Suzuki, Y.; Wada, K. Degradation of amyotrophic lateral sclerosis-linked mutant Cu,Zn-superoxide dismutase proteins by macroautophagy and the proteasome. J. Biol. Chem. 2006, 281, 30524-30533. [CrossRef]

161. Kopito, R.R. Aggresomes, inclusion bodies and protein aggregation. Trends Cell Biol. 2000, 10, 524-530. [CrossRef]

162. Bedford, L.; Hay, D.; Devoy, A.; Paine, S.; Powe, D.G.; Seth, R.; Gray, T.; Topham, I.; Fone, K.; Rezvani, N.; et al. Depletion of $26 \mathrm{~S}$ proteasomes in mouse brain neurons causes neurodegeneration and Lewy-like inclusions resembling human pale bodies. J. Neurosci. 2008, 28, 8189-8198. [CrossRef] [PubMed]

163. Niu, C.; Mei, J.; Pan, Q.; Fu, X. Nigral degeneration with inclusion body formation and behavioral changes in rats after proteasomal inhibition. Stereotact. Funct. Neurosurg. 2009, 87, 69-81. [CrossRef]

164. Anderson, P.; Kedersha, N. RNA granules. J. Cell Biol. 2006, 172, 803-808. [CrossRef] [PubMed]

165. Johnston, J.A.; Ward, C.L.; Kopito, R.R. Aggresomes: A cellular response to misfolded proteins. J. Cell Biol. 1998, 143, 1883-1898. [CrossRef] [PubMed]

166. García-Mata, R.; Bebök, Z.; Sorscher, E.J.; Sztul, E.S. Characterization and dynamics of aggresome formation by a cytosolic GFP-chimera. J. Cell Biol. 1999, 146, 1239-1254. [CrossRef]

167. Fournier, M.-J.; Gareau, C.; Mazroui, R. The chemotherapeutic agent bortezomib induces the formation of stress granules. Cancer Cell Int. 2010, 10, 12. [CrossRef] [PubMed]

168. Fujita, K.; Maeda, D.; Xiao, Q.; Srinivasula, S.M. Nrf2-mediated induction of p62 controls Toll-like receptor-4-driven aggresome-like induced structure formation and autophagic degradation. Proc. Natl. Acad. Sci. USA 2011, 108, 1427-1432. [CrossRef]

169. Galindo-Moreno, M.; Giráldez, S.; Sáez, C.; Japón, M.Á.; Tortolero, M.; Romero, F. Both p62/SQSTM1-HDAC6dependent autophagy and the aggresome pathway mediate CDK1 degradation in human breast cancer. Sci. Rep. 2017, 7, 10078. [CrossRef]

170. Chitiprolu, M.; Jagow, C.; Tremblay, V.; Bondy-Chorney, E.; Paris, G.; Savard, A.; Palidwor, G.; Barry, F.A.; Zinman, L.; Keith, J.; et al. A complex of C9ORF72 and p62 uses arginine methylation to eliminate stress granules by autophagy. Nat. Commun. 2018, 9, 2794. [CrossRef]

171. Vadlamudi, R.K.; Joung, I.; Strominger, J.L.; Shin, J. p62, a phosphotyrosine-independent ligand of the SH2 domain of p56lck, belongs to a new class of ubiquitin-binding proteins. J. Biol. Chem. 1996, 271, 20235-20237. [CrossRef]

172. Bjørkøy, G.; Lamark, T.; Brech, A.; Outzen, H.; Perander, M.; Overvatn, A.; Stenmark, H.; Johansen, T. p62/SQSTM1 forms protein aggregates degraded by autophagy and has a protective effect on huntingtin-induced cell death. J. Cell Biol. 2005, 171, 603-614. [CrossRef] [PubMed]

173. Pankiv, S.; Clausen, T.H.; Lamark, T.; Brech, A.; Bruun, J.-A.; Outzen, H.; Øvervatn, A.; Bjørkøy, G.; Johansen, T. p62/SQSTM1 binds directly to Atg8/LC3 to facilitate degradation of ubiquitinated protein aggregates by autophagy. J. Biol. Chem. 2007, 282, 24131-24145. [CrossRef] [PubMed] 
174. Seibenhener, M.L.; Babu, J.R.; Geetha, T.; Wong, H.C.; Krishna, N.R.; Wooten, M.W. Sequestosome 1/p62 is a polyubiquitin chain binding protein involved in ubiquitin proteasome degradation. Mol. Cell. Biol. 2004, 24, 8055-8068. [CrossRef] [PubMed]

175. Itakura, E.; Mizushima, N. p62 Targeting to the autophagosome formation site requires self-oligomerization but not LC3 binding. J. Cell Biol. 2011, 192, 17-27. [CrossRef] [PubMed]

176. Komatsu, M.; Waguri, S.; Koike, M.; Sou, Y.-S.; Ueno, T.; Hara, T.; Mizushima, N.; Iwata, J.-I.; Ezaki, J.; Murata, S.; et al. Homeostatic levels of p62 control cytoplasmic inclusion body formation in autophagy-deficient mice. Cell 2007, 131, 1149-1163. [CrossRef]

177. Nagaoka, U.; Kim, K.; Jana, N.R.; Doi, H.; Maruyama, M.; Mitsui, K.; Oyama, F.; Nukina, N. Increased expression of p62 in expanded polyglutamine-expressing cells and its association with polyglutamine inclusions. J. Neurochem. 2004, 91, 57-68. [CrossRef]

178. Lundgren, J.; Masson, P.; Mirzaei, Z.; Young, P. Identification and characterization of a Drosophila proteasome regulatory network. Mol. Cell. Biol. 2005, 25, 4662-4675. [CrossRef]

179. Kuusisto, E.; Suuronen, T.; Salminen, A. Ubiquitin-binding protein p62 expression is induced during apoptosis and proteasomal inhibition in neuronal cells. Biochem. Biophys. Res. Commun. 2001, 280, $223-228$. [CrossRef]

180. Thompson, H.G.R.; Harris, J.W.; Wold, B.J.; Lin, F.; Brody, J.P. p62 overexpression in breast tumors and regulation by prostate-derived Ets factor in breast cancer cells. Oncogene 2003, 22, 2322-2333. [CrossRef]

181. Nakaso, K.; Yoshimoto, Y.; Nakano, T.; Takeshima, T.; Fukuhara, Y.; Yasui, K.; Araga, S.; Yanagawa, T.; Ishii, T.; Nakashima, K. Transcriptional activation of p62/A170/ZIP during the formation of the aggregates: Possible mechanisms and the role in Lewy body formation in Parkinson's disease. Brain Res. 2004, 1012, 42-51. [CrossRef]

182. Pan, J.-A.; Sun, Y.; Jiang, Y.-P.; Bott, A.J.; Jaber, N.; Dou, Z.; Yang, B.; Chen, J.-S.; Catanzaro, J.M.; Du, C.; et al. TRIM21 ubiquitylates sqstm1/p62 and suppresses protein sequestration to regulate redox homeostasis. Mol. Cell 2016, 61, 720-733. [CrossRef] [PubMed]

183. Sha, Z.; Schnell, H.M.; Ruoff, K.; Goldberg, A. Rapid induction of p62 and GABARAPL1 upon proteasome inhibition promotes survival before autophagy activation. J. Cell Biol. 2018, 217, 1757-1776. [CrossRef] [PubMed]

184. Radhakrishnan, S.K.; Lee, C.S.; Young, P.; Beskow, A.; Chan, J.Y.; Deshaies, R.J. Transcription factor Nrf1 mediates the proteasome recovery pathway after proteasome inhibition in mammalian cells. Mol. Cell 2010, 38, 17-28. [CrossRef] [PubMed]

185. Marshall, R.S.; Li, F.; Gemperline, D.C.; Book, A.J.; Vierstra, R.D. Autophagic degradation of the $26 \mathrm{~S}$ proteasome is mediated by the dual atg8/ubiquitin receptor RPN10 in arabidopsis. Mol. Cell 2015, 58, 1053-1066. [CrossRef] [PubMed]

186. Marshall, R.S.; McLoughlin, F.; Vierstra, R.D. Autophagic turnover of inactive 26S proteasomes in yeast is directed by the ubiquitin receptor cue 5 and the hsp42 chaperone. Cell Rep. 2016, 16, 1717-1732. [CrossRef] [PubMed]

187. Cohen-Kaplan, V.; Livneh, I.; Avni, N.; Fabre, B.; Ziv, T.; Kwon, Y.T.; Ciechanover, A. p62- and ubiquitin-dependent stress-induced autophagy of the mammalian $26 \mathrm{~S}$ proteasome. Proc. Natl. Acad. Sci. USA 2016, 113, E7490-E7499. [CrossRef] [PubMed]

188. Marshall, R.S.; Vierstra, R.D. Eat or be eaten: The autophagic plight of inactive $26 \mathrm{~S}$ proteasomes. Autophagy 2015, 11, 1927-1928. [CrossRef]

189. Cuervo, A.M.; Palmer, A.; Rivett, A.J.; Knecht, E. Degradation of proteasomes by lysosomes in rat liver. Eur. J. Biochem. 1995, 227, 792-800. [CrossRef]

190. Dengjel, J.; Høyer-Hansen, M.; Nielsen, M.O.; Eisenberg, T.; Harder, L.M.; Schandorff, S.; Farkas, T.; Kirkegaard, T.; Becker, A.C.; Schroeder, S.; et al. Identification of autophagosome-associated proteins and regulators by quantitative proteomic analysis and genetic screens. Mol. Cell. Proteom. 2012, 11, M111.014035. [CrossRef]

191. Ren, C.; Liu, J.; Gong, Q. Functions of autophagy in plant carbon and nitrogen metabolism. Front. Plant Sci. 2014, 5, 301. [CrossRef]

192. Haracska, L.; Udvardy, A. Cloning and sequencing a non-ATPase subunit of the regulatory complex of the Drosophila 26S protease. Eur. J. Biochem. 1995, 231, 720-725. [CrossRef] [PubMed] 
193. van Nocker, S.; Sadis, S.; Rubin, D.M.; Glickman, M.; Fu, H.; Coux, O.; Wefes, I.; Finley, D.; Vierstra, R.D. The multiubiquitin-chain-binding protein Mcb1 is a component of the 26S proteasome in Saccharomyces cerevisiae and plays a nonessential, substrate-specific role in protein turnover. Mol. Cell. Biol. 1996, 16, 6020-6028. [CrossRef] [PubMed]

194. Üstün, S.; Hafrén, A.; Liu, Q.; Marshall, R.S.; Minina, E.A.; Bozhkov, P.V.; Vierstra, R.D.; Hofius, D. Bacteria exploit autophagy for proteasome degradation and enhanced virulence in plants. Plant Cell 2018, 30, 668-685. [CrossRef] [PubMed]

195. Waite, K.A.; De-La Mota-Peynado, A.; Vontz, G.; Roelofs, J. Starvation Induces Proteasome Autophagy with Different Pathways for Core and Regulatory Particles. J. Biol. Chem. 2016, 291, 3239-3253. [CrossRef] [PubMed]

196. Nemec, A.A.; Howell, L.A.; Peterson, A.K.; Murray, M.A.; Tomko, R.J. Autophagic clearance of proteasomes in yeast requires the conserved sorting nexin Snx4. J. Biol. Chem. 2017, 292, 21466-21480. [CrossRef] [PubMed]

197. Meiners, S.; Heyken, D.; Weller, A.; Ludwig, A.; Stangl, K.; Kloetzel, P.-M.; Krüger, E. Inhibition of proteasome activity induces concerted expression of proteasome genes and de novo formation of Mammalian proteasomes. J. Biol. Chem. 2003, 278, 21517-21525. [CrossRef]

198. Radhakrishnan, S.K.; den Besten, W.; Deshaies, R.J. p97-dependent retrotranslocation and proteolytic processing govern formation of active Nrf1 upon proteasome inhibition. Elife 2014, 3, e01856. [CrossRef] [PubMed]

199. Koizumi, S.; Irie, T.; Hirayama, S.; Sakurai, Y.; Yashiroda, H.; Naguro, I.; Ichijo, H.; Hamazaki, J.; Murata, S. The aspartyl protease DDI2 activates Nrf1 to compensate for proteasome dysfunction. Elife 2016, 5. [CrossRef]

200. Weyburne, E.S.; Wilkins, O.M.; Sha, Z.; Williams, D.A.; Pletnev, A.A.; de Bruin, G.; Overkleeft, H.S.; Goldberg, A.L.; Cole, M.D.; Kisselev, A.F. Inhibition of the Proteasome $\beta 2$ Site Sensitizes Triple-Negative Breast Cancer Cells to $\beta 5$ Inhibitors and Suppresses Nrf1 Activation. Cell Chem. Biol. 2017, 24, 218-230. [CrossRef]

201. Sekine, H.; Okazaki, K.; Kato, K.; Alam, M.M.; Shima, H.; Katsuoka, F.; Tsujita, T.; Suzuki, N.; Kobayashi, A.; Igarashi, K.; et al. O-GlcNAcylation Signal Mediates Proteasome Inhibitor Resistance in Cancer Cells by Stabilizing NRF1. Mol. Cell. Biol. 2018. [CrossRef]

202. Fardini, Y.; Dehennaut, V.; Lefebvre, T.; Issad, T. O-GlcNAcylation: A New Cancer Hallmark? Front. Endocrinol. (Lausanne) 2013, 4, 99. [CrossRef]

203. Biswas, M.; Phan, D.; Watanabe, M.; Chan, J.Y. The Fbw7 tumor suppressor regulates nuclear factor E2-related factor 1 transcription factor turnover through proteasome-mediated proteolysis. J. Biol. Chem. 2011, 286, 39282-39289. [CrossRef] [PubMed]

204. Tsuchiya, Y.; Morita, T.; Kim, M.; Iemura, S.; Natsume, T.; Yamamoto, M.; Kobayashi, A. Dual regulation of the transcriptional activity of Nrf1 by $\beta$-TrCP- and Hrd1-dependent degradation mechanisms. Mol. Cell. Biol. 2011, 31, 4500-4512. [CrossRef] [PubMed]

205. Dikic, I. Proteasomal and autophagic degradation systems. Annu. Rev. Biochem. 2017, 86, 193-224. [CrossRef] [PubMed]

206. Venugopal, R.; Jaiswal, A.K. Nrf2 and Nrf1 in association with Jun proteins regulate antioxidant response element-mediated expression and coordinated induction of genes encoding detoxifying enzymes. Oncogene 1998, 17, 3145-3156. [CrossRef] [PubMed]

207. Ohtsuji, M.; Katsuoka, F.; Kobayashi, A.; Aburatani, H.; Hayes, J.D.; Yamamoto, M. Nrf1 and Nrf2 play distinct roles in activation of antioxidant response element-dependent genes. J. Biol. Chem. 2008, 283, 33554-33562. [CrossRef] [PubMed]

208. Miao, W.; Hu, L.; Scrivens, P.J.; Batist, G. Transcriptional regulation of NF-E2 p45-related factor (NRF2) expression by the aryl hydrocarbon receptor-xenobiotic response element signaling pathway: Direct cross-talk between phase I and II drug-metabolizing enzymes. J. Biol. Chem. 2005, 280, 20340-20348. [CrossRef]

209. Hochmuth, C.E.; Biteau, B.; Bohmann, D.; Jasper, H. Redox regulation by Keap1 and Nrf2 controls intestinal stem cell proliferation in Drosophila. Cell Stem Cell 2011, 8, 188-199. [CrossRef]

210. Holmström, K.M.; Baird, L.; Zhang, Y.; Hargreaves, I.; Chalasani, A.; Land, J.M.; Stanyer, L.; Yamamoto, M.; Dinkova-Kostova, A.T.; Abramov, A.Y. Nrf2 impacts cellular bioenergetics by controlling substrate availability for mitochondrial respiration. Biol. Open 2013, 2, 761-770. [CrossRef] 
211. Meakin, P.J.; Chowdhry, S.; Sharma, R.S.; Ashford, F.B.; Walsh, S.V.; McCrimmon, R.J.; Dinkova-Kostova, A.T.; Dillon, J.F.; Hayes, J.D.; Ashford, M.L.J. Susceptibility of Nrf2-null mice to steatohepatitis and cirrhosis upon consumption of a high-fat diet is associated with oxidative stress, perturbation of the unfolded protein response, and disturbance in the expression of metabolic enzymes but not with insulin resistance. Mol. Cell. Biol. 2014, 34, 3305-3320. [CrossRef]

212. Jang, J.; Wang, Y.; Lalli, M.A.; Guzman, E.; Godshalk, S.E.; Zhou, H.; Kosik, K.S. Primary Cilium-Autophagy-Nrf2 (PAN) Axis Activation Commits Human Embryonic Stem Cells to a Neuroectoderm Fate. Cell 2016, 165, 410-420. [CrossRef]

213. Chio, I.I.C.; Jafarnejad, S.M.; Ponz-Sarvise, M.; Park, Y.; Rivera, K.; Palm, W.; Wilson, J.; Sangar, V.; Hao, Y.; Öhlund, D.; et al. NRF2 Promotes Tumor Maintenance by Modulating mRNA Translation in Pancreatic Cancer. Cell 2016, 166, 963-976. [CrossRef] [PubMed]

214. Korovila, I.; Hugo, M.; Castro, J.P.; Weber, D.; Höhn, A.; Grune, T.; Jung, T. Proteostasis, oxidative stress and aging. Redox Biol. 2017, 13, 550-567. [CrossRef] [PubMed]

215. Pickering, A.M.; Linder, R.A.; Zhang, H.; Forman, H.J.; Davies, K.J.A. Nrf2-dependent induction of proteasome and $\mathrm{Pa} 28 \alpha \beta$ regulator are required for adaptation to oxidative stress. J. Biol. Chem. 2012, 287, 10021-10031. [CrossRef]

216. Cui, W.; Min, X.; Xu, X.; Du, B.; Luo, P. Role of Nuclear Factor Erythroid 2-Related Factor 2 in Diabetic Nephropathy. J. Diabetes Res. 2017, 2017, 3797802. [CrossRef]

217. Sha, Z.; Goldberg, A.L. Proteasome-mediated processing of Nrf1 is essential for coordinate induction of all proteasome subunits and p97. Curr. Biol. 2014, 24, 1573-1583. [CrossRef]

218. Panieri, E.; Saso, L. Potential applications of NRF2 inhibitors in cancer therapy. Oxid. Med. Cell. Longev. 2019, 2019, 8592348. [CrossRef] [PubMed]

219. Kouroku, Y.; Fujita, E.; Jimbo, A.; Kikuchi, T.; Yamagata, T.; Momoi, M.Y.; Kominami, E.; Kuida, K.; Sakamaki, K.; Yonehara, S.; et al. Polyglutamine aggregates stimulate ER stress signals and caspase-12 activation. Hum. Mol. Genet. 2002, 11, 1505-1515. [CrossRef] [PubMed]

220. Wu, X.; Rapoport, T.A. Mechanistic insights into ER-associated protein degradation. Curr. Opin. Cell Biol. 2018, 53, 22-28. [CrossRef] [PubMed]

221. Iurlaro, R.; Muñoz-Pinedo, C. Cell death induced by endoplasmic reticulum stress. FEBS J. 2016, 283, 2640-2652. [CrossRef]

222. Rutkowski, D.T.; Kaufman, R.J. A trip to the ER: Coping with stress. Trends Cell Biol. 2004, 14, $20-28$. [CrossRef] [PubMed]

223. Wang, M.; Kaufman, R.J. Protein misfolding in the endoplasmic reticulum as a conduit to human disease. Nature 2016, 529, 326-335. [CrossRef]

224. Harding, H.P.; Zhang, Y.; Ron, D. Protein translation and folding are coupled by an endoplasmic-reticulumresident kinase. Nature 1999, 397, 271-274. [CrossRef]

225. Harding, H.P.; Zhang, Y.; Bertolotti, A.; Zeng, H.; Ron, D. Perk is essential for translational regulation and cell survival during the unfolded protein response. Mol. Cell 2000, 5, 897-904. [CrossRef]

226. Yoshida, H.; Matsui, T.; Yamamoto, A.; Okada, T.; Mori, K. XBP1 mRNA is induced by ATF6 and spliced by IRE1 in response to ER stress to produce a highly active transcription factor. Cell 2001, 107, 881-891. [CrossRef]

227. Calfon, M.; Zeng, H.; Urano, F.; Till, J.H.; Hubbard, S.R.; Harding, H.P.; Clark, S.G.; Ron, D. IRE1 couples endoplasmic reticulum load to secretory capacity by processing the XBP-1 mRNA. Nature 2002, 415, 92-96. [CrossRef]

228. Lee, A.-H.; Iwakoshi, N.N.; Glimcher, L.H. XBP-1 regulates a subset of endoplasmic reticulum resident chaperone genes in the unfolded protein response. Mol. Cell. Biol. 2003, 23, 7448-7459. [CrossRef]

229. Acosta-Alvear, D.; Zhou, Y.; Blais, A.; Tsikitis, M.; Lents, N.H.; Arias, C.; Lennon, C.J.; Kluger, Y.; Dynlacht, B.D. $\mathrm{XBP1}$ controls diverse cell type- and condition-specific transcriptional regulatory networks. Mol. Cell 2007, 27, 53-66. [CrossRef]

230. Yamamoto, K.; Sato, T.; Matsui, T.; Sato, M.; Okada, T.; Yoshida, H.; Harada, A.; Mori, K. Transcriptional induction of mammalian ER quality control proteins is mediated by single or combined action of ATF6alpha and XBP1. Dev. Cell 2007, 13, 365-376. [CrossRef] 
231. Adachi, Y.; Yamamoto, K.; Okada, T.; Yoshida, H.; Harada, A.; Mori, K. ATF6 is a transcription factor specializing in the regulation of quality control proteins in the endoplasmic reticulum. Cell Struct. Funct. 2008, 33, 75-89. [CrossRef]

232. Ogata, M.; Hino, S.; Saito, A.; Morikawa, K.; Kondo, S.; Kanemoto, S.; Murakami, T.; Taniguchi, M.; Tanii, I.; Yoshinaga, K.; et al. Autophagy is activated for cell survival after endoplasmic reticulum stress. Mol. Cell. Biol. 2006, 26, 9220-9231. [CrossRef] [PubMed]

233. Fujita, E.; Kouroku, Y.; Isoai, A.; Kumagai, H.; Misutani, A.; Matsuda, C.; Hayashi, Y.K.; Momoi, T. Two endoplasmic reticulum-associated degradation (ERAD) systems for the novel variant of the mutant dysferlin: Ubiquitin/proteasome ERAD(I) and autophagy/lysosome ERAD(II). Hum. Mol. Genet. 2007, 16, 618-629. [CrossRef] [PubMed]

234. Deegan, S.; Koryga, I.; Glynn, S.A.; Gupta, S.; Gorman, A.M.; Samali, A. A close connection between the PERK and IRE arms of the UPR and the transcriptional regulation of autophagy. Biochem. Biophys. Res. Commun. 2015, 456, 305-311. [CrossRef] [PubMed]

235. Kim, B.-W.; Kwon, D.H.; Song, H.K. Structure biology of selective autophagy receptors. BMB Rep. 2016, 49, 73-80. [CrossRef] [PubMed]

236. Avila, A.; Silverman, N.; Diaz-Meco, M.T.; Moscat, J. The Drosophila atypical protein kinase C-ref(2)p complex constitutes a conserved module for signaling in the toll pathway. Mol. Cell. Biol. 2002, 22, 8787-8795. [CrossRef] [PubMed]

237. Xu, D.; Shan, B.; Sun, H.; Xiao, J.; Zhu, K.; Xie, X.; Li, X.; Liang, W.; Lu, X.; Qian, L.; et al. USP14 regulates autophagy by suppressing K63 ubiquitination of Beclin 1. Genes Dev. 2016, 30, 1718-1730. [CrossRef]

238. Lee, M.J.; Lee, B.-H.; Hanna, J.; King, R.W.; Finley, D. Trimming of ubiquitin chains by proteasome-associated deubiquitinating enzymes. Mol. Cell. Proteom. 2011, 10, R110.003871. [CrossRef]

239. Hao, R.; Nanduri, P.; Rao, Y.; Panichelli, R.S.; Ito, A.; Yoshida, M.; Yao, T.-P. Proteasomes activate aggresome disassembly and clearance by producing unanchored ubiquitin chains. Mol. Cell 2013, 51, 819-828. [CrossRef]

240. Nanduri, P.; Hao, R.; Fitzpatrick, T.; Yao, T.-P. Chaperone-mediated $26 \mathrm{~S}$ proteasome remodeling facilitates free K63 ubiquitin chain production and aggresome clearance. J. Biol. Chem. 2015, 290, 9455-9464. [CrossRef]

241. Kawaguchi, Y.; Kovacs, J.J.; McLaurin, A.; Vance, J.M.; Ito, A.; Yao, T.P. The deacetylase HDAC6 regulates aggresome formation and cell viability in response to misfolded protein stress. Cell 2003, 115, 727-738. [CrossRef]

242. Pandey, U.B.; Nie, Z.; Batlevi, Y.; McCray, B.A.; Ritson, G.P.; Nedelsky, N.B.; Schwartz, S.L.; DiProspero, N.A.; Knight, M.A.; Schuldiner, O.; et al. HDAC6 rescues neurodegeneration and provides an essential link between autophagy and the UPS. Nature 2007, 447, 859-863. [CrossRef] [PubMed]

243. Lee, J.-Y.; Koga, H.; Kawaguchi, Y.; Tang, W.; Wong, E.; Gao, Y.-S.; Pandey, U.B.; Kaushik, S.; Tresse, E.; $\mathrm{Lu}$, J.; et al. HDAC6 controls autophagosome maturation essential for ubiquitin-selective quality-control autophagy. EMBO J. 2010, 29, 969-980. [CrossRef] [PubMed]

244. Gabrielsen, M.; Buetow, L.; Nakasone, M.A.; Ahmed, S.F.; Sibbet, G.J.; Smith, B.O.; Zhang, W.; Sidhu, S.S.; Huang, D.T. A General Strategy for Discovery of Inhibitors and Activators of RING and U-box E3 Ligases with Ubiquitin Variants. Mol. Cell 2017, 68, 456-470. [CrossRef] [PubMed]

245. Fajner, V.; Maspero, E.; Polo, S. Targeting HECT-type E3 ligases-insights from catalysis, regulation and inhibitors. FEBS Lett. 2017, 591, 2636-2647. [CrossRef] [PubMed]

(C) 2019 by the authors. Licensee MDPI, Basel, Switzerland. This article is an open access article distributed under the terms and conditions of the Creative Commons Attribution (CC BY) license (http://creativecommons.org/licenses/by/4.0/). 